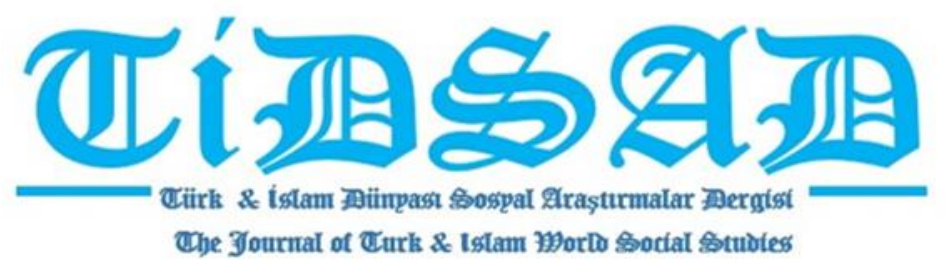

Yıl: 8, Sayı: 30, Eylül 2021, s. 101-126

\title{
Tarık ÇETINKAYA
}

tarcet@gmail.com

Doç. Dr. Hüsamettin KARATAŞ

Frrat Üniversitesi, FDB Dinler Tarihi, dr.karatash@gmail.com

\section{ELAZIĞ İLİ ULUOVA YÖRESINNDEKİ DOĞUMLA İLGİLİ HALK INANIŞLARININ DİNLER TARIHII AÇISINDAN DEĞERLENDİRILMESİ ${ }^{1}$}

Özet

Halk inanışlarının ve uygulamalarının temelinde insanoğlunun hastalık, çaresizlik ve yalnızlıktan kaynaklı korkularını yenme; bununla birlikte kutsal olana sığınma, kutsiyet atfedilenden medet umma ve kötücül güçlerin zararlarını bertaraf etme düşüncesi yatmaktadır. Elazığ ili Uluova yöresindeki doğumla ilgili halk inançlarının Dinler Tarihi açısından değerlendirilmesini konu alan bu çalışmada, özellikle doğum öncesinde, doğum esnasında ve doğum sonrasında ortaya çıkan bir takım inanış ve uygulamaların halk arasında nasıl yaşandığı ve yaşatıldığı tespit edilmeye çalışılmışıı. Söz konusu halk inanışları Dinler Tarihi açısından ele alınırken; deskriptif, tarihi, fenomolojik ve mukayeseli metotların yanı sıra alan araştırması, gözlem ve mülakat tekniklerinden faydalanma suretiyle elde edilen veriler objektif bir şekilde değerlendirilmiştir. Nitekim insan hayatının başlangıç aşaması olan doğum, geçiş dönemleri arasında önemli bir yere sahiptir. Her geçiş döneminin olduğu gibi doğumla alakalı inanış ve uygulamaların da kendisine has birtakım karakteristik özellikleri vardır. Bu çerçevede Uluova yöresindeki doğumla ilgili inanış, gelenek, töre, ayin, dinsel ve büyüsel uygulamalar benzerlikleri ve farklı1ıklarıyla ele alınmaya çalışı1mıştır.

Anahtar Kelimeler: Uluova Yöresi, Halk İnanışları, Doğum, Çocuk. Dinler Tarihi

\footnotetext{
${ }^{1} \mathrm{Bu}$ çalışma; "Elazı̆̆ İli Uluova Yöresi Halk İnanışları ve Dinler Tarihi Açısından Değerlendirilmesi” adlı Yüksek Lisans Tezinden faydalanılarak türetilmiştir.
} 


\title{
FOLK BELIEFS ABOUT BIRTH IN ELAZIG PROVINCE ULUOVA REGION EVALUATION IN TERMS OF THE HISTORY OF RELIGIONS
}

\begin{abstract}
Overcoming human fears of sickness, helplessness and loneliness on the basis of folk beliefs and practices. However, there is the idea of taking refuge in the sacred, seeking help from those who are attributed with holiness, and eliminating the harms of evil forces. In this study, which deals with the evaluation of folk beliefs about birth in the Uluova region of Elazig in terms of the History of Religions, it has been tried to determine how some beliefs and practices that emerged especially before, during and after birth were lived and kept alive among the people. While the folk beliefs in question are discussed in terms of the History of Religions; The data obtained by using descriptive, historical, phenomenological and comparative methods as well as field research, observation and interview techniques were evaluated objectively. As a matter of fact, birth, which is the beginning stage of human life, has an important place among the transition periods. As with every transitional period, beliefs and practices related to birth also have some unique characteristics. In this context, the beliefs, traditions, customs, rituals, religious and magical practices related to birth in the Uluova region have been tried to be discussed with their similarities and differences.
\end{abstract}

Keywords: Uluova Region, Folk Beliefs, Birth, Child, History of Religions

\section{GÍRIŞ}

Halk inanışlarının ve uygulamalarının temelinde insanoğlunun hastalık, çaresizlik ve yalnızlıktan kaynaklı korkularını yenme; bununla birlikte kutsal olana sığınma, kutsiyet atfedilenden medet umma ve kötücül güçlerin zararlarını bertaraf etme düşüncesi yatmaktadır. ${ }^{2}$ İnsanlığın tarihi aynı zamanda dinlerin de varoluş sürecini içermektedir. İlk insanlarla başlayan bu süreç binlerce yıldır birlikte devam etmektedir. Her dini sistemin ya da dinsel oluşumun benzer ya da farklı yanları söz konusudur. Ancak bunların her biri özü itibariyle biriciktir. Dini sistemler insan hayatından bağımsız düşünülemez. Dolayısıyla insan hayatının dönüm noktaları olarak ifade ettiğimiz süreçler aslında kendi içerisinde farklı inanışların ve uygulamaların ortaya çıkmasına zemin hazırlamıştır. Bu inanış ve uygulamalar insanların bazen yapması bazen de uzak durması gereken durumları ifade edebilir. Genelde bu süreçler doğum, evlenme ve ölüm olgusun merkeze alır ve geçiş dönemi olarak adlandırılır.

Elazığ ili Uluova yöresindeki doğumla ilgili halk inançlarının Dinler Tarihi açısından değerlendirilmesini konu alan bu çalışmada, özellikle doğum öncesinde, doğum esnasında ve doğum sonrasında ortaya çıkan bir takım inanış ve uygulamaların halk arasında nasıl yaşandığ ve yaşatıldığ 1 tespit edilmeye çalışılmıştır. Söz konusu halk inanışları Dinler Tarihi açısından ele alınırken; deskriptif, tarihi, fenomolojik ve mukayeseli metotların yanı sıra alan araştırması,

\footnotetext{
${ }^{2}$ Sedat Veyis Örnek, Türk Halk Bilimi, Ankara 2000, s. 131.
} 
gözlem ve mülakat tekniklerinden faydalanma suretiyle elde edilen veriler objektif bir şekilde değerlendirilmiştir. Nitekim insan hayatının başlangıç aşaması olan doğum, geçiş dönemleri arasında önemli bir yere sahiptir. Her geçiş döneminin olduğu gibi doğumla alakalı inanış ve uygulamaların da kendisine has birtakım karakteristik özellikleri vardır. Bu çerçevede Uluova yöresindeki doğumla ilgili inanış, gelenek, töre, ayin, dinsel ve büyüsel uygulamalar benzerlikleri ve farklı1ıklarıyla ele alınmaya çalışılmıştır.

$\mathrm{Bu}$ araştırmadaki temel amaç unutulmaya veya kaybolmaya yüz tutmuş bazı değerlerin yanı sıra bazı geleneklerin kayıt altına alınmak suretiyle sonraki nesillere aktarımını sağlamaktır. Ülkemizin çeşitli bölgelerinde ve yörelerinde benzer çalışmalar yapılmış ve yapılmaya devam etmektedir. Söz konusu çalışmalar esas itibariyle binlerce y1llık Türk halk kültürünü oluşturan öğelerin, değişen dinamiklere rağmen toplum tarafından nasıl yaşatıldığını gözler önüne sermektedir. Bu yüzden sadece Türk halk kültürünün değil aynı zamanda Türk halk dini geleneğinin de toplumsal düzeyde yaşayan hafızası konumundaki inanışların ve çeşitli ritüellerin sonraki nesillere doğru kanallardan aktarımı oldukça önemlidir.

\section{ELAZIĞ İLİ ULUOVA YÖRESİ DOĞUMLA İLGILİ HALK İNANIŞLARI}

Doğum olgusu insan neslinin devamı için gereklidir. Doğumu meşru kılan kurumsal yapının temeli ise aile kurumuyla mümkündür. Nitekim aile, Türk toplumunda önemli bir yere sahiptir. Aile, toplumu oluşturan yapının en küçük modelidir. Güçlü ve sağlam aile yapısı, toplumları ayakta tutan önemli bir yapı taşıdır. Çünkü aile, bilgi ve görgünün, örf ve âdetlerin öğrenildiği, yaşatıldığı ve sonraki nesillere aktarıldığı bir yerdir. Ailenin korunması ve devamı sadece toplumun değil aynı zamanda dini hayatın devamlılı̆̆ içinde gereklidir. Geleneksel Türk toplumunda aile olunabilmesinin şartlarından bir tanesi de çocuk sahibi olunmasıdır. Geleneksel Türk aile yapısı içinde kutsiyet atfedilen ocak veya baba ocağı tabirleri özü itibariyle geçmiş ile geleceği birbirine bağlayan mukaddes bir bağdır. Bu bağın müesses varlığını ve devamlılığını sağlayan ise doğumdur. Bundan dolayı evlenip çocuk sahibi olmak oldukça önemlidir. Ancak bazen çiftlerin isteği ile bazen de istenmesine rağmen her evli çiftin çocuk sahibi olamadığ durumlar yaşanmaktadır. Bu durumda, maalesef, çocuk sahibi olmayan ya da olamayan insanlara eksik/yarım gözüyle bakılmaktadır. Bu yüzden çocuk isteyen evli çiftler önce tıbbi yolları denerler. Daha sonra çocuk sahibi olmak isteyip de olmayan aileler; ata mezarlarını, evliya türbelerini ziyaret edip dilek tutarlar. Onlardan himmet/medet beklerler. Bunun yanında kutsal kabul edilen ağaçlara bez/çaput bağlayıp adaklarda bulunurlar.

Türkiye'nin her yerinde olduğu gibi Elazığ İli Uluova yöresinde de doğum ve çoğalmayla ilgili çeşitli halk inanışları görülmektedir. İmkânlar dâhilinde yöredeki doğumla alakalı inanışlar tespit edilmeye çalışılmıştır. Ancak ulaşamadığımız ya da tespit edemediğim bazı inanış ve uygulamaların var olma ihtimalini, bir şerh düşerek, ifade etmekte fayda görmekteyiz. Bu çerçevede yöredeki doğum ile ilgili halk inanışları doğum öncesi, doğum esnası ve doğum sonrası olmak üzere üç başlık altında incelemiş ve değerlendirilmiştir.

\section{Elazığ İli Uluova Yöresinde Doğum Öncesi Halk İnanışları}

Ailenin en önemli özelliklerinden birisi, neslin devamını güvenli bir biçimde sağlamasıdır. Bunun için her sağlıklı anne ve baba adayının ilk isteği sağlıklı bir çocuk sahibi olarak 


\section{Elazı̆̆ İli Uluova Yöresindeki Doğumla İlgili Halk İnanışlarının Dinler Tarihi Açısından} Değerlendirilmesi

toplumdaki "çocuk, ailede ocağ1 tüttürür"” ifadesinin getirmiş olduğu sevince muhatap olmaktır. Sadece Türk toplumunda değil neredeyse bütün toplumlarda çocuk ailede ve cemiyette gücün ve dayanışmanın artması anlamına gelir. Aksi durum söz konusu olduğunda ise toplumdan topluma değişmekle birlikte çeşitli negatif algılara neden olabilmektedir. Bu meyanda çocuğu olmayan kadın ve erkek için Uluova yöresinde "kısır, zürriyetsiz, kör ocak, ocağ 1 körelmiş" gibi ifadeler kullanılarak bu kişilerin bazen bilerek bazen de bilmeden rencide edildikleri bilinmektedir. Zira evliliklerinin üzerinden belli bir süre geçtikten sonra özellikle çocuk sahibi olamayan çiftlerden, yakın akrabaları kısa zamanda çocuk yapmalarını istemektedir. Belli bir zamandan sonra şayet çocuk olmuyorsa, önce tıbbi çareler aranır ardından ise özellikle kadın için halk hekimliği olarak da isimlendirilen bir takım "kocakarı" uygulamalarına başvurulur. Çeşitli sebeplerden dolayı doktora gidemeyen, doktora gitmekten çekinen veya hekime gittiği halde çocuğu olmayan kadınlar, "analık duygusunu tatmak, ailedeki yerini sağlamlaştırmak ve çevrenin kınayıcı baskısından kurtulmak" " için çeşitli teşhis ve tedavi yöntemlerine başvurur. Anne adaylarının başvurduğu bu inanış ve uygulamaların tümünü halk inanışları çerçevesinde değerlendirmek mümkündür. Bu inanış ve uygulamaların bir kısmı dinsel-büyüsel, bir kısmı da halk hekimliği ile ilgilidir.

Uluova yöresinde dinsel sayılabilecek nitelikteki uygulamalarının başında ata mezarlarını ve evliya türbelerini ziyaret etmek gelmektedir. Bu türden kutsal kabul edilen mekânlara giden anne adayları genelde çocuk sahibi olmak için adak adar ve dilek tutarlar. Bu meyanda kutsiyet atfedilen bazı ağaçlara çaput bağlamak, baba veya evliya mezarları başında saçı saçmak ve kurban sunmak; çocuk dileyenlerin en yaygın uygulamaları arasında yer almaktadır. Kaynaklarda örneğin Dede Korkut hikayelerinde çocuk üzerine kurgulanmış anlatımlarda rastlandığı gibi eski Türk gelenekleri çerçevesinde çocuk sahibi olmak isteyenlerin, Tanrının rızasını kazanmak için açları doyurduğu, çıplakları giydirdiği ve ağzı dualı kişilerin dualarını aldığı ifade edilmektedir. Nitekim bazı destanlarımızda, çocuk sahibi olmak isteyenlerin elma ağacının dibinde yattıkları ya da elma bahçelerinin olduğu yerlerde yuvarlandıkları, kutlu pınar başlarında oturdukları ve kutlu kişi mezarlarını ziyaret ettikleri zikredilmektedir. ${ }^{5}$

İnsanlar zaman içerisinde, karşılaştığı sorunlar karşısında farklı bir takım tutum ve davranışlar geliştirmiş ve bunların arkasına sığınmak mecburiyetinde kalmışlardır. Nesilden nesile geçen bu tutum ve davranışlar toplumumuz içinde halk inanışları olarak karşımıza çıkmıştır. Bu halk inanışlarının en fazla görüldüğü durumlardan birisi de doğum öncesidir. Doğum öncesi halk inanışları henüz çocuk ana rahmine düşmeden önce başlamaktadır. Uluova yöresinde çocuğun olması ile ilgili uygulamalar gelin isteme olayıyla başlar. İstenilecek gelinin ailesinde veya geçmişinde kısır olanlar, çocuğu olmayanlar; çocuğu olup da yaşamayanlar varsa, bu gelinin istenmesine iyi bakılmamaktadır. Bunun sebebi istenilecek gelinin de kısır olacağı inanışının hâkim olmasıdır. Bu uygulamalar eskiye nazaran pek görülmemektedir.

Çocuğun olmasıyla ilgili inanışların bir diğeri de düğün sırasındadır. Düğün evinin çatısına veya evin yüksek bir yerine, dügün evini belli etmek için uzun bir sırığa ay yıldızlı bayrak asılır, bayrak düğün sonuna kadar dalgalandırılır. Gelin erkek evine getirilince, bayrağın sivri ucuna

\footnotetext{
${ }^{3}$ Sami Kılıç, Türk Halk İnanışlarında Yiyecek ve İçecekler, Elazığ 2012, s. 18; Sedat Veyis Örnek, Türk Halk Bilimi, s. 131.

${ }^{4}$ Sedat Veyis Örnek, Geleneksel Kültürümüzde Çocuk, Ankara 1979, s. 2.

${ }^{5}$ Abdulkadir Kıyak, Elazı̆̆ ve Yöresinde Ziyaret Yerleri, Ankara 2012, s. 105-125.
} 


\section{Elazığ İli Uluova Yöresindeki Doğumla İlgili Halk İnanışlarının Dinler Tarihi Açısından} Değerlendirilmesi

kırmızı bir elma konur. Gelin evin avlusundan içeri girince bayrakta asılı olan elma evin büyüğü veya düğüne gelen ziyaretçiler tarafından silahla vurularak parçalanır. Daha önceden hazırlanmış olan; içinde şeker, buğday, darı, para ve elmanın olduğu çeşitli yiyecekler gelinin üzerine serpilir. Ayrıca gelin, evin avlusundan içeri girince; damat evin damında durarak gelinin kafasına bir elma atar. Damat elmayı gelinin kafasına isabet ettirir. Burada atılan elmayla, daha sonra olması muhtemel kısırlığın önüne geçilmiş olacağına inanılır 6 . Dolayısıyla burada ismi zikredilen elma ve ağacı, doğurganlığı sembolize etmektedir. Ayrıca gelin erkek evine getirildiğinde; erkek çocuğu olması için gelinin kucağına ve yatağına bir erkek çocuk verilir. Gelinin kucağına verilen çocuğun cinsiyeti ne ise doğacak ilk çocuğun cinsiyetinin de aynı olacağına inanılır. Burada gelinin kucağına verilen erkek çocuk, soyun devamını sağlamak, ailenin adını sürdürmek, baba ocağını tüttürmek, mirasın dağılmasını önlemek ve insanlar arasındaki güç dengesini kurmada önemli bir unsur olarak görülür. Bilhassa erkeklerin savaşlarda kaybedilmesi sebebiyle evin, ocağın başsız kalmaması ve erkeğin, eve ekmek getiren bir statüde olması, erkek çocuğu önemli kılmaktadır. Uluova ve çevresinde, evlendikten belli bir süre sonra çocuğu olmayan çiftlerin çocuk sahibi olabilmeleri için başvurdukları yollardan biri türbe, yatır vb. yerleri ziyaret etmeleridir. Bu ziyarette yapılan uygulamaların başında; namaz kılmak, kurban kesmek, dua etmek ve dilekte bulunma gelir. Bu ziyaret yerlerinden halkın en çok tercih ettikleri yerler ise bölgede bulunan ziyaret yerleri ve Harput'ta bulunan evliyaların mezarları ziyaret edilir. Bu minvalde özellikle Murat Baba ve Üryan Baba türbelerinin ön plana çıktı̆̆ını söylemek mümkündür. ${ }^{7}$ Çocuğu olmayan kadınların ebegümeci denilen bir otun haşlanarak kadının karnına bağlanması veya nefesi kuvvetli bir hocaya gidilerek muska yazılması, belirli ot süt karıştırılarak buharına oturtulması uygulamalarına rastlanmaktadır. ${ }^{8}$

Uluova yöresinde insanların ani ve şiddetli bir şekilde korkmaları, kız ve erkek çocukların küçük yaşlarda ağır bir şeyler kaldırmaları neticesinde çocuklarının olmayacağına inanılır. Bölgede çocuğunu devamlı düşüren veya çocukları devamlı küçük yaşta ölen kadınların beddua aldıklarından dolayı veya cin çarpması sonucu bu sorunla karşı karşıya kaldıklarına inanılmaktadır. ${ }^{9}$ Bilindiği üzere kadının hamile olduğu adet kesilmesinden, bazı bedeni rahatsızlıklardan ve karnının büyümesinden anlaşılır. Kadın doktora başvurarak hamile kalıp kalmadığını kesin olarak öğrenebilir. Yörede çocuk bekleyen bir kadına "hamile, gebe, yüklü, karnı burnunda, iki canl, bebek bekliyor, dolu" gibi isimler verilir. Bunun yanı sıra "hasta ya da hasta kadın" ş̧eklinde tanımlamalarda söz konusudur. Nitekim hamilelik boyunca veya doğum esnasında karşılaşılan kişiler tarafindan "Allah kurtarsın, Allah bir nefeste kurtarsın, Allah bir avazda kurtarsın" gibi dualar esas itibariyle bu olayın bir nevi hastalık biçiminde algılanmasından ve zorlu bir sürecin olumlu neticelenmesi için bir yakarış olduğunu söylemek mümkündür. ${ }^{10}$

Yörede kadının hamile kaldığı anlaşıldıktan sonra toplumdaki değeri artar ve kendisine daha fazla önem verilir. Durum öncelikle kadının annesine bildirilir. Kocasına gizlice söylenir. Bu tür

\footnotetext{
${ }^{6}$ Rıfat Araz, Harput'ta Eski Türk İnançları ve Halk Hekimliği, Atatürk Kültür Dil ve Tarih Yüksek Kurumu Atatürk Kültür Merkezi Yayını No: 108, Ankara 1995, s. 90.

${ }^{7}$ Kıyak, Elazığ ve Yöresinde Ziyaret Yerleri, s. 75-76

${ }^{8}$ Nazife Yıldırım, 1965/Tadım ; Zübeyde Buytoz 1973/ Ballıca

${ }^{9}$ Firdevs Karataş, 1951, Şahsuvar Köyü: Kıymet Erol, 1955, Sarıyakup Köyü

${ }^{10}$ Güler Şirin, 1957, Şahsuvar Köyü; Zübeyde Aktaş, 1970, Yalnız Köyü: Mürüvet Vural, 1951, Yedigöze Köyü
} 


\section{Elazığ İli Uluova Yöresindeki Doğumla İlgili Halk İnanışlarının Dinler Tarihi Açısından} Değerlendirilmesi

konular eskiden açık olarak söylenmez; gizli tutulurdu. ${ }^{11}$ Son yıllarda bu durum değişmiştir. Hamilelik döneminde kadının düşük yapmaması için kadın koruma altına alınır ve kendisi de bazı şeylerden korunur. Özellikle düşük yapan kadınlar için doğum öncesi bir takım tedbirler alınır. Bu kadınlar doktor kontrolüne alınır. Ayrıca ağır yük kaldırmaz, yüksekten atlatılmaz, halı-kilim gibi şeyler silkeletilmez, yükseğe uzandırılmaz, merdivenden yavaşça indirilir, ilk ve son ayda fazla iş yaptırılmaz. ${ }^{12}$ Nitekim yaygın halk inanışlarına baktığımızda hamile kadının genellikle bir takım kısıtlamalarla karşı karşıya kaldığı görülmektedir. Kadının hamileliği sırasında baktığı, yediği, içtiği ve yaptıklarıyla dünyaya getireceği çocuk arasında bir ilişki olacağı endişesinden dolayı bazı olaylara karşı tedbirler alınmıştır. ${ }^{13}$ Hamile kadının karnındaki çocuğun şekillenmeye başladığı dönemde, dışarıdan gelebilecek herhangi bir şeyin çocuk üzerinde etkili olacağı inanışı yaygındır. Bu çerçevede Uluova yöresinde hamile kadınların karanlık çöktükten sonra tek başlarına dışarıya çıkmamaları, evin içerisinde ve dışında dikkatli hareket etmeleri, kaynamış suyu ve kor halindeki ateşi, gelişi-güzel yerlere dökmemeleri gerektiği tembih edilir. ${ }^{14}$

Uluova yöresindeki halk, karanlık bastıktan sonra "yerlerin ve göklerin mühürlendiğine” inanır. Yerin ve gögün mühürlenmesi, yapılacak bazı eylemlerin veya işlerin yapılmaması ya da gündüz saatlerine ertelenmesi anlamı taşımaktadır. Bu yüzden güneş battıktan sonra bazı olumsuzlukların meydana gelebileceğine olan inanışa bağlı olarak özellikle gece saatlerinde çok daha dikkatli olunması gerekir. Çünkü bir takım gizil güçlerin veya gözle görülmeyen varlıkların anne adayına ve doğacak çocuğa zarar verme ihtimalinin olduğu düşünülmektedir. Bunu önlemek için hamile kadının yanında üzerlik ve tütsü yakılır, ortaya çıkan dumanın ve tütsü kokusunun kadının üstüne başına sinmesi sağlanır. Böylece hamile kadının ve çocuğun korunacağına inanılır. ${ }^{15}$

Yörede hamile kadının köpek, yılan, akrep veya ürkütücü bir şey görürse çocuğunun düşeceği; onun rüyasında korkması halinde ise doğacak olan çocuğu etkileneceği inanışı mevcuttur. $\mathrm{Bu}$ nedenle hamile bir kadının rüyasında korkmaması için yastığının altına Kur'an ve dua kitapları konulur. Hamile kadın özellikle mezarlığa götürülmez; ölü bir insana bakmasına izin verilmez. Çünkü doğacak olan çocuğun halsiz kalacağına ve yüzünün sarı kesileceğine inanılır. Ayrıca kadının hamileliği süresince, dünyaya gelecek olan çocuğun ömrünün uzun olması için kendi saçını kestirmez ve dişini çektirmez. ${ }^{16}$

Uluova yöresinde, hamilelik döneminde evli çiftler ve aileleri özellikle yatırları, baba ve evliya türbelerini ziyaret geleneğini sürdürmektedir. Söz konusu gelenek halk inanışları açısından önemli bir yere sahiptir. Bu çerçevede gebe olan kadın, türbe ziyaretine gittiğinde eliyle herhangi bir yere veya herhangi bir şeye dokunmaz. Şayet dokunursa elini vücuduna sürmez. Aksi halde vücudunun neresine dokunmuşsa çocuğun vücudunda, o bölgede "ziyaret beni" olarak adlandırılan; siyah veya kırmızı lekelerin oluşacağına inanılır. Mülakat yaptığımız kadınların hemen hemen hepsinin bu olaya dikkat çekmesi, en yakınlarından örnekler vermeleri

\footnotetext{
${ }^{11}$ Nuray Günaylı, 1968, Yedigöze Köyü: Fatma Yalçın 1956, Gedikyolu Köyü

${ }^{12}$ Hanım Çimen, 1960, Tadım Köyü: Fatma Işık, 1965, Koçkale Köyü

${ }^{13}$ Naciye Güneş ,1947, Korucu Köyü: Aysel Şanlı, 1948, Elmapınarı Köyü

${ }^{14}$ Hülya Tunç, 1965, Yukarı İçme Köyü

15 Tayyibe Karakaş, 1944, Sarıkamış Köyü

${ }^{16}$ Songül Turhan, 1968, Kuyulu Köyü: Gülay Polat, 1953, Akçakiraz :Pakize Aydın,1939, Gedikyolu Köyü
} 


\section{Elazığ İli Uluova Yöresindeki Doğumla İlgili Halk İnanışlarının Dinler Tarihi Açısından} Değerlendirilmesi

oldukça dikkat çekmektedir. Bu noktada örnek veren kadınların bir de uyarıda bulunduklarını ifade etmemiz gerekir. Şöyle ki; geleneklerimize göre dua ederken ellerimizi avuç ayası yukarı gelecek şekilde tutar, dua bittikten sonra iki elimizi yüzümüze süreriz. Bu her türlü dua ve çeşitli ritüelleriden sonra tekrarlanan çok yaygın bir adettir. Bu minvalde yatır ziyaretinde bulunan gebe kadınların; dua ettikten sonra özellikle söz konusu yaygın adetten, yani elleri yüze sürme eyleminden, mutlaka uzak durmaları tembihlenmektedir. Aksi halde doğacak çocuğun yüzünde istenmeyen büyüklükte bir leke olabilir. Hatta hamile kadınların evliya mezarlarını tek başına ziyaret etmemeleri, gideceklerse bu tür bir eylemi engelleyecek dikkatli bir yakını ile gitmelerini de tavsiye edilmektedir. ${ }^{17}$

Yörede hamile kadının ayna karşısında süslenmesi halinde çocuğun güzel olacağına, hamileliği sırasında kime dikkatli bir şekilde bakarsa doğacak çocuğun o kişiye daha çok benzeyeceğine inanılır. Bu yüzden hamile kadın, hamileliği boyunca güzel huylu ve güzel yüzlü insanlara bakmaya gayret eder. Kötü huylu, çirkin, sakat ve hasta insanlardan uzak durmaya çalışır ve onlara bakmaz. Kadın, hamileliği sırasında bir hayvana bile dikkatli bakacak olursa doğacak çocuğun bir yönüyle baktığı hayvana benzeyeceğine inanılır. ${ }^{18}$ Doğan çocuğun dudaklarında her hangi bir yarık olursa; halk arasında "yarık dudakll" , "yarık damaklı" veya "tavşan dudaklı" gibi isimler verilmesinin sebebi; kadının hamileliğinde tavşan eti yediği veya tavşana baktığ için çocuğun dudağının böyle olduğuna inanılır. Eğer hamileliğinde balıketi yerse doğacak çocuğun ağız yapısının balık ağzına benzeyeceğine inanılır. ${ }^{19}$ Hamilelikte kadının sakız çiğnemesi de uygun görülmez. Çünkü çocuğun sümüklü olacağına inanılır. Ayrıca hamile kadınların hamilelikte toprak yedikleri görülür. Toprağın yenmesiyle çocuğun toprak gibi sağlam ve alçakgönüllü olacağına inanılır. ${ }^{20}$ Hamile kadın Ay'a çok bakarsa ve ayvayı çokça yerse doğacak çocuğun güzel olacağı inanışı vardır. Bazı kadınlar doğacak çocukları gamzeli olsun diye ayva yediklerini veya böyle yapanların çocuklarının gamzeli olduğu inancını dile getirdiler. Hamilelik döneminde aşeren kadının, canının istediği şeyin tadına bakması; aksi halde çocukta bir zarara sebep olacağı inancı Uluova yöresinde de oldukça yaygındır. ${ }^{21}$ Nitekim aşerme deyiminin asl1, "yiyeceklerden tiksinme" anlamına gelen "aş yerme"dir. Aş yerme deyimi zamanla anlam kaymasına uğramış ve "hamile kadının bazı yiyecekleri canının çekmesi, onları tatmak istemesi” anlamında aşermeye dönüşmüştür". Türkiye'nin pek çok bölgesinde olduğu gibi Uluova yöresinde de aşerme döneminde hamile kadının canının çektiği yiyecek ile doğacak çocuğun cinsiyeti arasında bir ilişkinin olduğu inancına rastlanmaktadır. Hamile kadın ekşi yiyecekleri aşerse kız, tatlı şeyleri aşerse erkek çocuğu doğuracağına inanılır. Bununla ilgili olarak halk arasında: "Ye ekşiyi doğur Ayşe'yi; ye tatllyı doğur atllyı" gibi ifadeler kullanılmaktadır. Özellikle bal, süt, yumurta; sebze, meyve ve tatlı gıdaların yenmesi tavsiye edilir. ${ }^{22}$ Hamile bir kadın, çalıntı bir yiyecek yerse dünyaya getireceği çocuğun ileride hırsızlık yapacağına inanılır ayrıca hamile kadınların maydanoz nane gibi bitkilerin yememesi içilmemesi gerekir bu gibi bitkiler çocuğun düşmesine sebep olabilir. ${ }^{23}$

\footnotetext{
${ }^{17}$ Emine Altan 1939, Şahsuvar Köyü: Miyase Gülcemal, 1950, Yolüstü Köyü

${ }^{18}$ Nesrin Ceyhan 1971, Kuyulu Köyü : Aygün Karakaya, 1967, Aşağı İçme :Nebahat Yavuz, 1967, MollaKöy Köyü

${ }^{19}$ Ece Şahin, 1941, Gedikyolu Köyü: Fatma Çakabay, 1947, Korucu Köyü

${ }^{20}$ Güllü Tan, 1957, Sarıyakup Köyü; Özgül Arslan 1968, Tadım Köyü

${ }^{21}$ Fethiye Taş, 1938, Yurtbaşı Köyü; Semahat Mutlu, 1963, Aşağı İçme Köyü

${ }^{22}$ Firdevs Bıyıkl1, 1939, Konakalmaz Köyü; Naciye Güneş, 1947, Korucu Köyü

${ }^{23}$ Muhlise Parlak, 1940, Şahsuvar Köyü
} 


\section{Elazığ İli Uluova Yöresindeki Doğumla İlgili Halk İnanışlarının Dinler Tarihi Açısından}

Değerlendirilmesi

Hamile kadınların doğuracağı çocuğun cinsiyeti hakkında, yörede çeşitli tahminler yapılmaktadır. Hamile bir kadın, eğer rüyasında armut görmüşse erkek çocuk, elma görmüş ise kız çocuk sahibi olacağına inanılır. Rüyada görülen bıçak, salatalık ve kabak erkek çocuğa; bilezik ve boncuk ise kız çocuğa yorumlanır. ${ }^{24}$ Çocuk, hamile kadının karnının sağ tarafında başını vurursa erkek; şayet karnın sol tarafında başını vurursa kız olacağına inanılır. Kadın hamileliği sırasında çok halsizlik hissederse, doğacak çocuğun kız olacağına inanılır. Kadın hamilelik döneminde, diğer dönemlerden daha güzel olursa erkek; çirkin olursa kız çocuğu doğuracağına inanılır. ${ }^{25}$ Doğumu yaklaşan anne adayının canı tatlı şeyler yemek isterse erkek çocuk; şayet canı ekşi şeyler yemek isterse kız çocuğu olacağına inanılır. Hamile kadının, kalça ve karın kısmının geniş olması halinde kız çocuğuna; kalça kısmının pek belli etmemesi halinde erkek çocuğu doğuracağına işaret sayılır. Hamile bir kadının, hamileliğinin ileriki dönemlerinde göbeğinin üzerinde şişkinlik varsa ve bu şişkinlik ileriye doğru ise çocuğun erkek olacağına inanılır. Eğer hamile kadının karnı bütün olarak şişkin ve oval bir hal alırsa doğacak çocuğun kız olacağına inanılır. ${ }^{26}$

Uluova yöresinde çocuk evin neşesi, dünyanın en güzel meyvesi olarak görülür. Bu sebepten çocuk Allah'ın bahşettiği en önemli nimetlerden biri olarak kabul edilir. Dolayısıyla çocuğun düşürülmesine ya da kürtaja katiyen rıza gösterilmez ve bu eylemler ayrıca günah olduğundan uzak durulur. Ancak hastalık, fakirlik ve çok çocuk sahibi olmak gibi nedenlerden dolay çocuğu düşürmek isteyen kadınlar da yok değildir. Bazı anne adaylarının ağır bir şeyler kaldırarak veya yüksekçe bir yere çıkıp atlayarak çocuk düşürmeye çalıştıkları anlatılmaktadır. ${ }^{27}$

Uluova yöresinde, doğum yaklaşınca çocuk için çeşitli hazırlıklar yapılır. Ailenin maddi durumu bu noktada önem arz eder. Her aile kendi durumuna göre çocuk için kıyafet, beşik, kundak hazırlar; imkânlar ölçüsünde bir oda tanzim etmeye çalışır. Mülakatlarda eskiden beşik alamayacak durumda olanların ise yakınlarından ödünç beşik aldıkları ve çocuk büyüyünce iade ettikleri ifade edildi. ${ }^{28}$

\section{Elazı̆ İli Uluova Yöresinde Doğum Esnasındaki Halk İnanışları}

Elazığ İli Uluova yöresinde doğum sırasındaki halk inanışları, esas itibariyle geleneksel Türk halk kültüründeki inanç ve uygulamalarla neredeyse aynıdır. Elbette bazı noktalarda özellikle Elazığ ve çevresinde görülen farklılıkları bünyesinde barındırmaktadır. Bilindiği üzere doğum, varoluşsal bir olgu içerisindeki mucizelere insanoğlunun bizzat iştirak ederek şahit olmasıdır. $\mathrm{Bu}$ olağanüstü mesele başından sonuna kadar çeşitli zorluklarla birlikte mutluluklara vesile olmaktadır. Nitekim doğumu bekleyenler için bu olay bir sevinç ve gurur vesilesidir. Çünkü her şeyden habersiz olarak doğan çocuk, anne için hem dokuz ay boyunca çeşitli zorluk ve meşakkatin son bulması; hem de annelik gibi ulvi bir mertebeye ulaşmanın müjdecisidir. Baba adayı için baba olmanın verdiği gurur; içinde bulunduğu toplumda kabul görmenin vesilesidir. Çocuk herkes için yeni bir umut, büyük bir aile olma yolunda atılan ilk adımdır. Çocuk sahibi olmak soyun devamı, ocağın tütmesi, kısırlık gibi korkuların son bulması ve geleceğe umutla

\footnotetext{
${ }^{24}$ Zabite Ural,1950, Konakalmaz Köyü; Fatma Yalçın, 1956, Gedikyolu Köyü

${ }^{25}$ Fahriye Kavuran, 1960, Kuyulu Köyü; Türkan Rençber, 1934, Gözebaşı Köyü

26 Tayyibe Karakaş, 1944, Sarıkamış Köyü; Fikriye Efe, 1966, Koçkale Köyü

${ }^{27}$ Nazmiye Gül, 1958, Şahsuvar Köyü: Sema Kaya,1970, Koçkale Köyü; Naile Aygün, 1956, Konakalmaz Köyü

${ }^{28}$ Nesrin Ceyhan, 1971, Kuyulu Köyü: Firdevs Bıyıklı, 1939, Konakalmaz Köyü
} 


\section{Elazığ İli Uluova Yöresindeki Doğumla İlgili Halk İnanışlarının Dinler Tarihi Açısından} Değerlendirilmesi

bakabilmenin vesilesidir. ${ }^{29}$ Doğum olayı meşakkatli bir durum olduğu için doğum yapacak kadın, doğacak çocuk ve doğum olayı ile ilgili olan herkes sıkıntılı bir süreçten geçer. Doğum sürecinin kusursuz olması için herkes elinden gelenin en iyisini yapmaya çalışır. ${ }^{30}$

Uluova yöresinde hamile bir kadının doğumu yaklaşınca imkanlar dahilinde hastaneye kontrol için aralıklarla götürülür. Doğum olayının sağlıklı bir şekilde yapılabilmesi için genellikle tam teşekküllü bir hastane tercih edilmektedir. Eskiden buna firsatı olmayan ve kırsal kesimlerde yaşayan insanlar da kendi evlerinde, tecrübeli ve yaşlı bir kadın tarafından doğumu yapılmaktaydı. Doğum olayıyla ilgilenen bu kadına Anadolu'nun birçok yerinde olduğu gibi Uluova yöresinde "ebe" denilmektedir. ${ }^{31}$ Doğum eğer evde yapılacaksa ebe kadın eve çağrılır. Bazı kadınlar hiç kimseye ihtiyaç duymadan kendi başlarına doğum yaparlar. Evde yapılan doğum geleneksel yöntemlerle gerçekleştirilir. Doğum sırasında kadının ve erkeğin bayan akrabaları doğuma yardımcı olurlar. Doğum esnasında erkekler ve yaşı büyük çocuklar evden uzaklaştırılır. ${ }^{32}$ Hamile kadının sancısı çok olduğu zaman kimseye söylenmez. Eğer sancı duyulursa doğumun zorlaşacağına, uzayacağına ve sancının artacağına inanılır. Hamile kadının sancıları başlayınca, doğumu yaptıracak ebe kadın tarafından muayene edilir. Çocuğun eğri veya doğru gelip gelmediğine bakar. Yöre halkına göre bebek, koldan gelirse eğri; baştan gelirse doğru demektir. Doğum esnasında bebek ters gelirse veya doğum zor olursa gebe kadın odada gezdirilir. Doğum yapacak kadına sık sık yürüyüş yaptırılır; beli ve karnı ovulur, ayrıca sıcak su ile banyo yaptırılır. Battaniye ve yorgan gibi şeylere sarılır. Doğumun kolay olabilmesi için hamile kadının yakınları, fakirlere sadaka verir; herkesten dua istenir. Ayrıca doğumun kolay olması için hamile kadına doğuma yakın hafif şeyler, tuzsuz ve acısız yemekler yedirilir. Anne adayının saç örgüleri çözülür, doğum sırasında kolay doğum yapmış kadınlar, doğum odasına alınır. Ancak günümüzde hastane ve sağlık hizmetleri iyi durumda olduğu için doğumların büyük bir oranı hastanelerde gerçekleşmektedir. ${ }^{33}$

\section{Elazığ İli Uluova Yöresinde Doğum Sonrası Halk İnanışları}

Elazığ İli Uluova yöresinde doğum sonrası halk inanışları, Anadolu'nun her köşesinde olduğu gibi sadece hamilelik dönemi değil doğum hadisesi ve sonrası ne kadar önemli ise bu yöredede o derece önemlidir. Zira yeni doğan çocuk, korunmaya, beslenmeye ve büyütülmeye muhtaçtır. Çocuğun tüm ihtiyaçlarını annesi ve ailesi karşılamakla yükümlüdür. Aile söz konusu temel ihtiyaçların karşılanmasının yanında inanışa dayalı bazı kurallara uymak ve bir takım pratikleri uygulamak mecburiyetindedir.

Uluova yöresinde doğum, yeni bir başlangıç sayılmakta ve doğum sayesinde bütün olumsuzlukların gitmesi; eski ve kötü olan şeylerin son bulması amacıyla yeni bir hayata, temiz bir sayfayla başlamaktır. Bu yüzden kadın, doğum yaptıktan sonra, önceden hazırlanmış olan özel yatağa yatırılır. Bu yatağın temiz ve yeni olmasına dikkat edilir. Bunun nedeni ise muhtemel olumsuzlukların yeni doğan çocuğu etkilememesidir. Yöredeki bazı köylerde yatağın renginin beyaz veya yeşil tonlarında olmasının önemli olduğu vurgulandı. Bununla birlikte yeni doğum yapan kadının bulunduğu yere süpürge, soğan ve sarımsak asılır. Ayrıca lohusa kadının

\footnotetext{
${ }^{29}$ Hasan Ayaz, 1957, Yalnız Köyü; Veli Başbaydar, 1968, Yünlüce Köyü

30 İbrahim Tan, 1956, Sarıyakup Köyü; Naci Meşe, 1953, Tadım Köyü

${ }^{31}$ Asiye Özcan 1945, Mollaköy Köyü; Safiye Ergün 1966, Aşağı İçme Köyü

${ }^{32}$ Fahriye Kavuran, 1960, Kuyulu Köyü; Fethiye Taş, 1938, Yurtbaşı Köyü

${ }^{33}$ Huriye Aydın, 1938, Şahsuvar Köyü; Müzeyyen Çak, 1963, Ballıca Köyü; Hamide Güler, 1969, Ürünveren Köyü
} 


\section{Elazığ İli Uluova Yöresindeki Doğumla İlgili Halk İnanışlarının Dinler Tarihi Açısından Değerlendirilmesi}

yastığının altına muska, ekmek, çuvaldız ve mendil konulur. Bu uygulamalar özü itibariyle "al basması" ya da "al karış" $ı$ inanışı ile doğrudan ilişsilidir. ${ }^{34}$

Çocuğun doğumu, ailesi için çok önemli bir muştudur. Çocuk doğduktan sonra doğumu yaptıran ebe kadın, eğer o müsait değilse akrabalardan biri doğumun iyi geçtiğini ve çocuğun cinsiyetini babasına ve yakınlarına bildirmek için dışarı çıkar ve babadan "müjde verme" denilen bahşişi ister. Bahşiş sözünü alan kadın, çocuğun cinsiyetini söyler. Muştu karşısında baba müjdeciye hediyesini verir. $\mathrm{Bu}$ hediye genelde para, elbise, koyun, keçi, altın vesaire cinsinden olup; miktarı ailenin mali durumuna göre değişiklik gösterir. Bazen de müjde verilirken, aile de daha önce doğan çocuklar kız ise doğacak çocuğun erkek olması istenir. Bu durumda eğer erkek çocuk müjdesi verilirse alınan bahşişin miktarı artabilir. Bunun tam aksine erkek çocukları var ve kız çocuk bekleniyorsa yine bolca bahşiş verilir. ${ }^{35}$ Uluıvva yöresinde, son yıllardaki uygulamalara bakıldığında, kız ve erkek çocuk ayrımının eskiden olduğu kadar kıymetli olmadığını söylemek mümkündür.

Uluova yöresinde sağlıklı bir şekilde doğmuş olan çocuğun göbek bağı, bıçak veya makasla göbekten dört parmak üstten kesildikten sonra "ebe" tarafından tuzlanarak bağlanır. Eskiden yörede çocuk doğduktan ve göbeği kesildikten sonra çocuğun bütün vücudunun tuzlandığı ifade edildi. Bu uygulamanın ise özellikle kokmaması, terlememesi ve pişmemesi için yapıldığı zikredildi. Çocuk tuzlama işlemi bittikten hemen sonra yıkanır. Genelde çocuk, yaz mevsiminde doğmuşsa hemen her gün yıkanır; eğer kışın dünyaya gelmişse havalar soğuk olduğu için belirli günlerde ve imkânlar nispetinde yıkanır. Çocuğu yıkama işi kırk gün devam eder. ${ }^{36}$

Yörede doğan çocukların göbek bağı le ilgili bazı pratikler vardır. Yeni doğan kız veya erkek çocukların göbek bağı, çocuklar ileriki hayatlarında kendileri, aileleri ve yaşadıkları toplum için ak1ll1, okumuş faydalı birer birey olsunlar diye okul bahçesine veya cami avlusuna uygun bir yere gömülür. Bazı aileler çocuklarının ileride olmasını istedikleri bir meslek gurubuna ait mekânlara, örneğin doktor olması niyetiyle hastane bahçesine, idareci olması maksadıyla kamu kurumlarına ait bir mekâna ya da kutsal sayılan bir yere göbek bağını gömdükleri sıklıkla rastlanan uygulamalar arasında sayılır. ${ }^{37}$

Göbeği kesilen ve tuzlanan ve tuzlandıktan sonra suyla yıkanan çocuk kundağa sarılır. Bunun için temiz bir yere önceden hazırlanmış büyükçe bir bez serilir. Daha sonra bunun üzerine ara bezi serilir. Bunun üzerine de hafifçe 1sitılmış özel bir toprak: "Kundak toprağı" konur. Yörede bu toprağa "höllük" adı verilir. Bu toprağın üzerine çocuğa zarar vermemesi ve toprağın çok 1slanmaması için küçük bir bez konur. Çocuğun başı dişarıda kalacak şekilde baştan ayağa kadar, bütün vücudu bu kundakla sarılır. Çocuğun kundağa sarılmasındaki gaye, çocuğun bütün vücudunu soğuktan, eklem yerlerindeki çıkıklardan korumak ve çocuk kucağa alınırken rahat tutulabilmesini sağlamak içindir. Ayrıca kundağa sarılan çocuğun "kambur, eğik bacakll" olmayacağına; uzun boylu ve dik duruşlu olacağına inanılır. Ayrıca bebeğin altı bağlanırken göbek kısmına, "göbeklik" konur. Bunun sebebi de kesilen göbek bağının zedelenmesini önlemek içindir. Kundağa konulduktan sonra çocuğun başı güzel görünümlü ve yuvarlak olsun

\footnotetext{
${ }^{34}$ Hadice Akbaş, 1954, Ürünveren Köyü; Atike Ayaz, 1956, Yalnız Köyü; Kıymet Erol, 1955, Sarıyakup Köyü

${ }^{35}$ Zabite Ural, 1950, Konakalmaz Köyü; Nazmiye Sarptaş, 1958, İçme; Maviye Ateşoğlu, 1960, Elmapınarı Köyü

${ }^{36}$ Emine Ökmen, 1972, Yedigöze Köyü; Cahide Coşkuner, 1961, Ürünveren Köyü

${ }^{37}$ Hanım Çimen, 1960, Tadım Köyü; Nazife Yıldıım, 1965, Tadım Köyü
} 


\section{Elazığ İli Uluova Yöresindeki Doğumla İlgili Halk İnanışlarının Dinler Tarihi Açısından} Değerlendirilmesi

diye yazma veya yöredeki tabirle "tülbent" sarılır. Çocuğun başının arka kısmı çıkıntılı olmasın diye kafasının altına hafifçe sert olan karton, ince bir tahta parçası gibi şeyler konur. Çoğun başı tülbentle bağlanır ki başı yamuk olmasın. Çocuğun büyüyünce halk arasında, "kepçe kulak, sivri kulak veya yapışık kulak" gibi, kulakta meydana gelebilecek şekil bozukluklarına engel olmak için; çocuk yatırılırken kulaklarının konumuna dikkat edilir. Ayrıca yeni doğan çocuğun, büyüdüğünde korkak olmaması için yastığının altına "blçak, ekmek, mushaf" konur. ${ }^{38}$

Uluova yöresinde mülakat yapılan bazı kişiler, eskiden çocuk doğduktan sonra beş ezan vakti geçmeden çocuğa meme verilmediği ifade ettiler. Meme yerine çocuğun, büyüdüğünde zekâs1 iyi olsun diye ağzına pekmez sürülürdü aktarıldı. Özellikle bal kullanılmadığını çünkü balı yiyen çocuğun lal veya kekeme olmasından korktuklarını dile getirdiler. Günümüzde bu tür uygulamaların çok nadir olduğu anlaşılmaktadır. Nitekim anne sütünün ne kadar önemli bir besin olduğunu artık herkes bilmektedir. Doğumdan hemen sonra ve ilk altı ay anne sütünden başka bir besin çocuğa verilmez. Anne, çocuğuna kendisinde barındırdığı özellikleri, sütü yoluyla aktarmaktadır. Anne sütüyle büyüyen çocukların, güçlü, zeki, iyi huylu ve sağlıklı olacağına inanılır. Dolayısıyla anne, çocuğunu emzirdiği dönemde yediği ve içtiği şeylerin helalinden olmasına önem verir. Çünkü çocuğun içtiği anne sütü kişiliğinin oluşmasında son derece önemlidir. Eğer anne haram bir şeyle beslenir ve sütünü çocuğa verirse çocuğun ileride hırsız olacağına, söz dinlemeyeceğine, kötü işlerle iştigal edeceğine inanılır. Bebekler ağladıklarında avutmak için boş meme verilirse, bu çocukların ileriki hayatlarında yalancı olacaklarına inanılır. Annenin sütü az olursa, ek olarak ya mama ya koyun ya da inek sütü verilir. Yöredeki bazı köylerde süt kardeşliği geleneği sürdürülse de özellikle süt kardeşliğinin ileride sıkıntı çıkarmaması için mümkün mertebe uzak durulur. ${ }^{39}$

Yörede çocuğu yaşamayanların çocuğun muhafazası için aldıkları bazı tedbirler vardır. Örneğin, çocuğu yaşamayan bazı ailelerin, çocuğun kendilerine ait olmadığı izlenimi vermeye çalışırlar. Bunun için çocuğa "yedi yamalı fistan" giydirilir. Aile yedi kapıdan yedi parça bez alır, bu bezlerden yedi yamalı elbise diker ve çocuğa giydirir. Böylece çocuğa zarar verecek olan kötücül güçler; çocuğun hangi aileye ait olduğunu bilemeyeceği için ona zarar veremeyeceğine inanılır. Bu uygulama çocuk yedi yaşına gelene kadar sürdürülür. ${ }^{40}$

Doğum olayından sonra hayata gözlerini yeni açan bebeği bekleyen en önemli merhale; çocuğun korunmasını, hayatı boyunca karakterini, geleceğini ve ileriki hayatındaki başarısını etkileyecek olan isimlerin çocuğa verilmesidir. Çocuğa konulan isim gelişigüzel seçilmez. Bundan dolayı Uluova yöresinde çocuğun doğduğu "belli mevsim, ay, vakit, gün ve gecelere" ilişkin adlara rastlanılmaktadır. Yörede yaşamış veya metfun bulunan "şehit, asker, paşa, âlim, ulu kişilere, atalara, kendisine hayranlık ve şükran duyulan kişilere" ait adlara rastlanır. ${ }^{41}$ Bunun yanında çocuğun doğduğu yer; doğduğu sıradaki hadiseler, ailenin maddi durumu, çocuğun babasının aile içindeki sosyal statüsü; gök ve ilgili adlara; sosyal hayatın içinde bazı

\footnotetext{
${ }^{38}$ Mürüvet Özcan, 1925, Mollaköy Köyü; Güler Polat, 1953, Akçakiraz; Fatma Çakmak, 1964, Dereboğazı Köyü

${ }^{39}$ Güllü Kama, 1940, Elmapınarı Köyü; Miyase Gülcemal, 1950, Yolüstü Köyü; Nuray Gömayc1, 1968, Yedigöze Köyü

${ }^{40}$ Firdes Karataş, 1951, Şahsuvar Köyü

${ }^{41}$ Hamide Güler, 1969, Ürünveren Köyü; Safiye Ergün, 1966, Aşağı İçme; Tayyibe Karakaş, 1944, Sarıkamış Köyü
} 


\section{Elazığ İli Uluova Yöresindeki Doğumla İlgili Halk İnanışlarının Dinler Tarihi Açısından Değerlendirilmesi}

sebeplere bağlı olan hadiselerle ilgili adlara; moda, kültür değişmeleri ve çocuğu kötü ruhların fenalıklarından korumak için verilen adlara rastlanmaktadır. ${ }^{42}$

Uluova yöresindeki bazı köylerde doğan çocuğa hemen isim verilirken bazen de ilk üç gün isim konulmadığı görülmektedir. Genellikle isim, anne ve baba adayları tarafından doğum olayı olmadan önce hazırlanmıştır. Yine de isim konusunda büyüklerin görüşü alınmaya çalışılır. Eğer isim üzerinde bir uzlaşı sağlanırsa çocuğun ismi hemen konur. Lakin aile büyügünün teklif ettiği isim, anne ve babanın belirlediği isimden farklı olursa, burada devreye genellikle göbek bağ 1 kesilirken konulan; halk arasında "göbek adı" olarak bilinen isim verilir. Çoğunlukla kutsal kitaplarda geçen adlar; aile büyüklerinin: anne, baba, dede, ninenin isimleri konulur. Bu isimler resmi kayıtta geçtiği gibi; kayda geçmeden de çocukların anne ve babaları, akrabaları ve yakınları tarafından kullanılır. Genellikle kimsenin gönlü kırılmasın diye, çocuğa hem "göbek $a d l$ " hem de "gerçek adı" verilir ve böyle hitap edilir. Yöredeki bazı köylerde isim verilirken, ismi verilmek istenen kişi sağ ise bu durumun ertelendiği, özellikle akrabalardan yakın zamanda ölmüş veya aile için değer atfeden ölmüş bir büyüğün adının verilmesi önemsenmektedir. ${ }^{43}$

Yörede çocuğa isim verilirken çevrede dindar olarak bilinen bir kişi, cami imamı veya evin büyüğ̈̈; abdest alır ve çocuğu kucağına alarak isim verme işlemine başlar. İlk önce çocuğun sağ kulağına "ezan" okunur, bu arada çocuk erkek ise "göbek adı", "Muhammed Mustafa" diye; kız ise "Fatma" diye seslenir. Daha sonra da çocuğun asıl ismini normal bir ses tonuyla üç defa söyler; daha sonra sol kulağına "kamet" okur, ardından yine çocuğun ismini üç defa söyleyerek en sonunda kısa bir dua yapar ve "ad verme" merasimi sona ermiş olur. ${ }^{44}$

Uluova yöresinde, aileden ve yakın akrabalardan genç yaşta veya talihsiz bir şekilde hayatını kaybeden bir kişinin adı; yeni doğan çocuğa verilerek ölen kişinin adının yaşatılacağına inanılır. Aileler, sağ olarak doğduktan sonra ölen çocuklarının isimlerini, sonraki çocukları da aynı cinsiyette olursa; ona verirler. Böylelikle bu çocuklarının yaşayacağına inanırlar. Ayrıca sürekli hastalanan, huzursuzluk çıkaran, çok ağlayan; aynı zamanda doğmuş olmalarına rağmen çelimsiz ve iflah olmayan çocuklarla; yürüme çağına geldiği halde yürümede sorun yaşayan çocukların adları, kendilerine ağır geldiği inancı ile tamamen değiştirilir. Yeni adından dolayı sıkıntılar yaşanacaksa, çocuğun mevcut adı, yöreye has bir ağız özelliğine büründürülerek "Firdevs ise Fidoş, Fatma ise Fatoş, Emine ise Emoş, İbrahim ise İboş, Mehmet ise Mamoş diye çağrnlır. ${ }^{45}$

Ülkemizin çoğu yerinde olduğu gibi Uluova yöresinde çocuğu olduğu halde yaşamayan annebaba kendi adlarını çocuklarına verirler. Çocuk kız olursa annenin, erkek olursa babanın adı verilir. Böylelikle çocuğun yaşı itibarı ile büyük birisi olarak algılanmasına vesile olacağına ve yaşayacağına inanılır. ${ }^{46}$ Ad koyma merasimlerinde öncelikli olan bir diğer hususta belli gün, ay, mevsim ve gecelerle ilgili adlara rastlanır. Cuma günü doğan çocuklara, "Cuma, Cumali”; Ramazan ayında doğan çocuklara "Oruç, Ramazan", Kadir gecesinde doğan çocuklara, "Kadir,

\footnotetext{
${ }^{42}$ Ayişe Aygün, 1939, Konakalmaz Köyü; İnci Dündar, 1961, Korucu Köyü; Türkan Rençber, 1934, Gözebaş1 Köyü

43 Sevim Gökdere, 1955, Şahsuvar Köyü; Muhlise Parlakdemir, 1940, Şahsuvar Köyü; Zabite Ural, 1950, Konakalmaz Köyü

${ }^{44}$ Tekçe Çetindağ, 1938, Akçakiraz; Ali Özcan, 1951, Mollaköy Köyü; Faik Üstündăg, 1937, Yukarı İçme Köyü ${ }^{45}$ Pakize Aydın,1939, Gedikyolu Köyü; Ramazan Işı1k, 1957, Koçkale Köyü; Cihan Çınar, 1964, Yolüstü Köyü

${ }^{46}$ Nurettin sever, 1941, Gedikyolu Köyü; Mustafa Sönmez, 1931, Gözebaş1 Köyü; Şahabettin Bayram, 1946, Korucu Köyü
} 


\section{Elazı̆̆ İli Uluova Yöresindeki Doğumla İlgili Halk İnanışlarının Dinler Tarihi Açısından Değerlendirilmesi}

Kadriye, Abdulkadir, Leyla" ; Kandil geceleri doğan çocuklara, "Miraç, Mevlüt, Mevlüde, Berat"; Arife günü doğan çocuklara, "Arif, Arife"; Hac zamanında dünyaya gelen çocuklara, "Hacı, Hacıali"; bayram günü doğan çocuklara, "Bayram, İsmail" adı verilebilmektedir. Seher ve şafak vakti doğanlara, "Seher, Şafak, Tan, Tanyeli, Taner, Tansu, Tankut, Tanju"; İlkbahar mevsiminde doğanlara "Bahar, Cemre, Yağmur, Filiz, Yeşim, Çiçek, Tomurcuk, Yaprak, Gül, Yasemin, Sümbül, Lale, Menekşe, Nergis" adı verilir. Yılın belirli aylarında doğanlara, "Nisan, Eylül, Kasım, Muharrem, Recep, Şaban, Ramazan, Şevval" gibi adlar verilir. ${ }^{47}$

Doğum olayından birkaç gün geçtikten sonra, kadında ve çocukta herhangi bir hastalık ve sıkıntı söz konusu değilse; akrabaları, yakınları ve komşuları doğum ziyaretine giderler. Doğum ziyaretiyle, hem kadına ve ailesine, geçmiş olsun dilekleri sunulur ve hem de aileye katılan çocuk için "hayırlı olsuna" ve "göz aydınlı̆̆ına" gidilir. Doğum ziyaretine gidenler kadına ve çocuğa iyi niyet dileklerini şu sözlerle ifade ederler: "Allah hayırlı etsin, Allah bağışlasın, Allah nazardan saklasın, gözünüz aydın, analı babalı büyüsün, geçmiş olsun” ; aradaki muhabbeti pekiştirmek için de kadına takı, yiyecek ve giyecek; çocuk için de takı ve elbiseler götürürler. $\mathrm{Bu}$ ziyaretleşmeler genellikle doğum yapan aileler tarafından beklenmekte, ziyaretçiler için de bir borç sayılmaktadır. Ziyarete gitmede akrabalık ve komşuluğun yakınlık ve uzaklığı, zenginlik ve fakirlik gibi etmenler, hediyenin miktarında ve özelliklerinde etkilidir. Kaynanalar genellikle gelinlerine "tam altın", çocuğa da "yarım altın" takarak bu olayı tebrik ederler. Doğum olduktan birkaç gün sonra, kadını ziyarete gidenler beraberinde tatlı götürürler. Bundaki amaç, doğum yapan kadının kendisini erken toparlamasına yardımcı olmak ve karın bölgesinin yumuşak kalmasını sağlamaktır. Genellikle ziyarete gelenlere lohusa şerbeti ikram edilir. ${ }^{48}$

Uluova yöresinde doğum yapan kadına "loğusa" denilmektedir. Loğusalık kırk gün devam etmektedir. Bu kırk günlük süre içerisinde "loğusa" olan kadın dışarıya çıkarılmaz, ağır şeyler kaldırmaz, soğuk şeyler yemez ve içmez, soğuktan korunur, eli öpülmez, loğusa kadın yalnız bırakılmaz; üzüntüden uzak tutulur. Loğusa kadın düğüne ve değirmene gitmez, kötü gözlü insanlara gösterilmez, loğusa kadının evine "et" sokulmaz. Ölü evinden, düğün evinden çıkan kimse loğusa ziyaretine gitmez. Loğusayı ziyarete gelen aynı gün başka loğusaya gitmez. Çocuk yalnız bırakılmaz, çocuğun bulunduğu yere "av tüfeği, tabanca ve av hayvanı" getirilmez, getirilecek olursa çocuk evden çıkarılır. Örneğin değirmenden "un” öğütülüp geldiği zaman çocuk evden çıkarılır. Çocuk "kırkll” iken, bulunduğu evde ölen veya yolculuğa çıkan olursa çocuğa "kırk basacağına" inanılır. Çocuğun yastı̆̆ının altına ekmek konur. Kadının yanında kocası, kaynanası, annesi, kız kardeşi veya küçük bir çocuk mutlaka yanında bulunur ve ihtiyaçlarını karşılar ${ }^{49}$

Uluova yöresinde doğum yapan kadın ve çocuk görünür ve görünmez tehlikelerden korunmaya çalış1ır. Görünmez olan bu varlıklardan biri de halk arasında "Alkarısı" diye bilinen gizli bir güçtür. ${ }^{50}$ Yöre halkı arasında "Alkarası, Albastı, Albis, Almis, Alanası, Alkızı" olarak da isimlendirilen Alkarısı veya Albasmasl; insan hayvan karışımı bir görünümde olduğuna inanılan

\footnotetext{
${ }^{47}$ Hülya Tunç, 1965, Yukarı İçme Köyü; Kemal Çelik, 1931, Akçakiraz Köyü

48 Baki Özçelik, 1932, Gözebaşı Köyü; Eco Şahin, 1941, Gedikyolu Köyü; Naciye Güneş, 1947, Korucu Köyü, Mustafa Kaya, 1954, Koçkale Köyü

${ }^{49}$ Firdevs Bıyıklı, 1939, Konakalmaz Köyü; Naciye Güneş, 1947, Korucu Köyü; Pembe Bağban, 1939, Şahsuvar Köyü; Ayişe Aygün, 1939, Konakalmaz Köyü

50 Nazmiye Gül, 1958, Şahsuvar Köyü: Sevim Gökdere, 1955, Şahsuvar Köyü; Sema Kaya,1970, Koçkale Köyü; Naile Aygün, 1956, Konakalmaz Köyü
} 


\section{Elazı̆̆ İli Uluova Yöresindeki Doğumla İlgili Halk İnanışlarının Dinler Tarihi Açısından Değerlendirilmesi}

ruh, şeytan, dev, peri veya cin" şeklinde tasavvur edilen, iri yarı, kırmızı giysili, uzun saçlı, yaşlı ve çirkin bir varlık şeklinde tasavvur edilir. Loğusa kadınlarla çocuklarının ölümüne sebep olan, doğumu zorlaştıran, "ailenin gelişim ve çoğalmasını engelleyen, bazı hayvanlara eziyet ederek onların kuvvet ve bereketlerini azaltan, efsanevi görünümü ile konuşan, duyan, hisseden, ailesi, yuvası, kabilesi bulunan bir varlık olduğuna inanılmaktadır. Ayrıca yakalanıp gücünden istifade edilen, "demir" vb. aletlerden korkan; yapısında insanlar için hastalık, korku ve ölüm gibi acı ve 1zdırap unsurlarını taşıyan "kötücül bir ruh" olduğu inancı hâkimdir. Alkarısının ahır, zibillik, samanlık, harabe, 1ssız yerlerde, karanlık ve kuytu köşelerde, kayalıklarda, dere ve su kenarlarında bulunduğuna inanılır. Olağanüstü yeteneklere sahip olduğu, şekilden şekle girdiği, korkutucu olduğu; yalnızları, gençleri, loğusa kadınları ve çocukları korkuttuğuna inanılır. Yalnız kalan kadınlara gelen "Alkarısı" ancak iğne, çuvaldız ve demirden yapılmış bir aletle uzaklaştırılır; aksi takdirde loğusa kadın ve çocuğun ciğerini göğsünden çıkaracağına inanılır. Türk kültür geleneğinde ve halk inanışlarına göre albastının tüfek sesinden, demirci ve ocaklılardan korktuğu varsayılmaktadır. ${ }^{51}$

Uluova yöresinde yeni doğan çocuk, havale (şiddetli ateş) geçirdiği zaman; annenin, çocuğunun gözlerini kapatıp yere "çivi" çakması istenir. Aksi takdirde çocuğun sakat kalacağına inanılır. ${ }^{52}$ Yeni doğan çocuğun kulağında akıntı olursa, çocuğun kulağına anne sütü damlatılır, çocuğun burnu yara olursa aynı işlem yapılır. ${ }^{53}$ Sarılık olan çocuğa "sarı tülbent" örtülür, eğer sarılık geçmezse altın madeninden yapılıış bir takı suya atılıp bu su ile çocuğa banyo yaptırılır. Çocuk sarılıktan şayet iyileşmezse alnına, kulağının arkasına ve topuğuna sarılık ocağındaki kişi tarafından özel bir bıçak veya kesici bir aletle, kan akıttırılır ve çocuğun alnına ve burnuna sürülür. Yaradan kan aktıkça hastalık da akar gider. Böylelikle çocuğun iyileşeceğine inanılır. ${ }^{54}$

Uluova yöresinde, çocuklar sık sık ağlayan ve tedavi edilemeyen çocukların nazara geldiğine inanılır. Nazar veya göz değmesi; halk arasında "kötü göz, pis göz, göz değmesi, göze gelme, kem göz, nazara gelme, nefese gelme, nefesi değme" gibi ifadelerle anlatılır. Yöre halkı arasında bazı kişilerin "kötü bakışa, kötü dile, kötü nefese" sahip olduklarına inanılır ve böylesi kişilerin nazarlarından korunmak için çeşitli önlemler alınır. İnsanın daha anne karnından başlayarak; bebekliği, çocukluğu, gençliği, olgunluğu, yürümesi, konuşması, ahlakı, evi, işi, bağı-bahçesi, ailesi, çocukları, mal varlığı gibi akla gelen her şeyi nazara hedef olabilir. Hatta bununla ilgili "mezarda yatan insanların çoğunun nazardan gittiğine" , "nazarın insanı mezara koyduğuna" inanılır. Dolayısıyla yöre halkı, keskin göze, kuvvetli dile ve güçlü nefese sahip olan kötü niyetli kişilerin bakışlarından, dillerinden ve nefeslerinden korunmaya çalışır. Bunun için çocuklarına kirli, eski ve yırtık elbiseler giydirirler. Nazar, psikolojik temelinde kıskançlık ve haset duyguları taşıyan kimselerde olduğuna inanılan insanlara ve cansız nesnelere bile zarar veren, bakışlardan firlayan çarpıcı ve öldürücü kuvvettir. Dolayısıyla bu vurucu kuvvetin ruhun dışa açılan iki noktasından, yani gözlerden fışkırarak kurbanına isabet ettiğine inanılır. ${ }^{55}$ Yörede

\footnotetext{
${ }^{51}$ Emine Ökmen, 1972, Yedigöze Köyü; Cahide Coşkuner, 1961, Ürünveren Köyü; Nesrin Ceyhan, 1971, Kuyulu Köyü: Firdevs Bıyıkl1, 1939, Konakalmaz Köyü

52 Nazmiye Gür, 1958, Sahsuvar Köyü

${ }^{53}$ Fatma Çakabay, 1947, Konakalmaz Köyü

${ }^{54}$ Güler Polat, 1953, Akçakiraz; Asiye Özcan, 1945, Mollaköy

55 Sevim Gökdere, 1955, Mürüvet Özcan, 1925, Mollaköy Köyü; Güler Polat, 1953, Akçakiraz; Fatma Çakmak, 1964, Dereboğazı Köyü; Şahsuvar Köyü; Muhlise Parlakdemir, 1940, Şahsuvar Köyü; Zabite Ural, 1950, Konakalmaz Köyü
} 


\section{Elazığ İli Uluova Yöresindeki Doğumla İlgili Halk İnanışlarının Dinler Tarihi Açısından} Değerlendirilmesi

nazar değmesin diye bahsi geçen kuvvetli dil ve nefesin, "kötü gözün etkisinden sakınmak için genellikle mavi boncuk ya da göz boncuğu olarak bilinen nazar boncuğu" bulundurulur. Ayrıca "Maşallah" yazısının, nazara karşı etkili olduğuna inanılır. Bunun için yeni doğmuş çocukların üzerinde taşınır. ${ }^{56}$ "Maşallah" yazısı, kötü gözlü ve kötü nefesli kimselerin bakışlarına ve sözlerine karşı bir koruma görevi görür. Çünkü bu türden kimseler baktıkları her hangi bir şeye elinde olmadan zarar verebilirler. Dolayısıyla baktıkları nesnenin üzerinde "Maşallah" yazısını görünce, gözü bu yazıya ilişecek ve ister istemez yazıyı okuyacaktır. Böylelikle baktığı şeye nazar etmeyecek ve nazara sebep olacak sözler de sarf edemeyecektir. ${ }^{57}$ Nazar ettiğine inanılan insanlarla karşılaşıldığı zaman, çocuğun kalçasını veya kişi kendi kalçasını mıncıklar. Ayrıca nazardan korunmak, göz değmesini önlemek için "kömür karası", ocak veya her hangi bir kabın altındaki isin, çocuğun alnına, ensesine, kulak arkasına veya göz kenarlarına sürülmesiyle nazardan kurtulacağına inanılır. Bu işlemin, gelecek kötülükleri önleyeceğine inanılır. ${ }^{58}$ Yeni doğan çocuğu görmeye gelenlerin çocuğun yüzünü açıp bakması pek hoş karşılanmaz. Bundan dolayı çocuğu görmeye gelenlerin "Maşallah" demesi beklenir. Bütün bu uygulamalara rağmen yine de çocuğa nazar değmiş ise çocuk, bu sefer de hocaya götürülür; üzerine dualar okunur ve muska yaptırılır. ${ }^{59}$

Doğum sırasında, anne ve doğacak çocuk daima risk altındadır. Bu risk doğumdan sonra da devam etmektedir. Bu risklerin en başında da anne veya çocuğun hastalanması ve hayatını kaybetmeleri gelmektedir. Bu tür olumsuzlukların nedeni ve onlardan korunma yollarının bulunması hep bilinmeyene, manevi güçlere bağlanır. ${ }^{60}$ Doğumdan kırk gün sonra çocuğu ve anneyi arıtmak, topluma katılmalarını sağlamak ve hastalıklardan, uğursuzluklardan korumak amacıyla "Kırklama" yapılmaktadır. Doğumun kırkıncı günü anne ve çocuk, hamamda veya banyoda yıkanarak temizlenir. En sonunda da bir tasa su konur. Yaşlı bir kadın başparmağını aynı şekilde kırk kere suya koyup çıkarır. Daha sonra bu su, loğusa kadının ve çocuğun başından aşağı dökülür. Kırk çıkarılınca bütün hastalık, uğursuzluk ve pisliklerin gittiği inancı mevcuttur. ${ }^{61}$

Uluova yöresinde sağlıklı bir şekilde doğan çocuğu bekleyen süreçlerden bir diğeri de çocuğun dişlerinin çıkmaya başlamasıdır. Genellikle dişi çıkan çocuklar, huysuzlanır, ağlar, elini ağzına koyup damaklarını kaşıtır; damaklarını kaşımak için ağzına annesinin parmaklarını koyar, bulmuş olduğu her hangi bir şeyle sürekli damağını kaşır. Çocukların ilk çıkan dişi halk arasında "Diş Hediği" olarak bilinen bir merasimle kutlanır. Eğer bu merasim yapılmazsa çocuğun dişlerinin geç ve zor çıkacağına inanılır. Diş hediği merasimi şu şekilde yapılır. Çocuğun ilk dişini aileden biri görür ama genellikle bu gizlenir. Dişi ilk gören dayı, amca, nine, dede veya bir başkası olursa, ilk dişi gördüğü için çocuğa hediye alması gerekir. Bundan sonra çocuğa verilirken, hedik denilen buğday haşlaması üzerine; "ceviz, tuz veya şeker" dövülerek serpilir. ${ }^{62}$ Yakın komşu ve akrabalar davet edilir. Çocuğu güzelce yıkadıktan sonra, elbiseleri giydirilir; hediyeleri verilir. Davet edilen misafirlere hedikler ikram edilir. Daha sonra tepsi

\footnotetext{
${ }^{56}$ Nahide Deringöl, 1964, Şahsuvar Köyü; Semahat Mutlu, 1963, Aşağı İçme Köyü

${ }^{57}$ Hadice Akbaş, 1954, Ürünveren Köyü; Atike Ayaz, 1956, Yalnız Köyü; Kıymet Erol, 1955, Sarıyakup Köyü

58 Özgür Güler, 1970, Ürünveren Köyü; Cemal Güllecemal, 1977, Yolüstü Köyü

${ }^{59}$ Zabite Ural, 1950, Konakalmaz Köyü

${ }^{60}$ Kiymet Karakoç, 1955, Elmapınarı Köyü

${ }^{61}$ Fikrinaz Aksu, 1950, Şahsuvar Köyü

${ }^{62}$ Fahriye Kavuran, 1960, Kuyulu Köyü, Safiye Ergün, 1966, Aşağ İçme Köyü
} 
içerisine "kalem, makas, ayna, tarak, bıçak, çakmak, altın, para, kitap ve Kur'an-ı Kerim" konur. Çocuk tepsinin içinden hangisini alırsa ileride seçeceği meslek hakkında yorumlar yapılır. Mesela; çocuk kalem alırsa, okuyacağına; makas alırsa, terzi; tarak ve ayna alırsa, berber; bıçak alırsa, kasap; altın ve para alırsa, kuyumcu, tüccar ve zengin; Kur'an-1 Kerim alırsa, din adamı veya dini bütün bir kişi olacağına inanırlar. ${ }^{63}$

Uluova yöresinde konuşma çağına geldiği halde konuşamayan veya kekeme olan çocukların konuşması içim; konuşamayan çocukların yanında Kur'an-1 Kerim'den "Yasin Suresi” okunur; çocukta Kur'an-1 Kerim'e yakın tutulur, surenin yarısına gelindiğinde Kur'an-1 Kerim aniden kapatılır ve yüksek bir ses çıkarılır. Eğer çocuk çıkan sesten korkup irkilirse dilinin açılacağına veya kekemeliğin sona ereceğine inanılır. Konuşma zorluğu çeken çocuklara, güzel sesli kuşların etinden yedirilir ki çocuğun sesi açılsın ve kuş gibi şakıyabilsin. Ayrıca kurban kesilir; eti fakirlere sadaka olarak dağıtılır, kurbanın dili pişirilerek çocuğa yedirilir veya kilidi dualar okunarak açılır ki çocuk konuşabilsin. Konuşma güçlüğü çeken çocuklar için diğer bir uygulama da, çocuğun ailesi cuma günü caminin kapısına bir kilit vururlar; bu kilidi cami imamı veya ağzı dualı birisi açacak olursa çocuklarının dilinde ki düğümün de bu sayede açılacağına inanırlar. Ayrıca konuşamayan çocukların konuşabilmesi için Cuma namazından sonra müezzin, cami anahtarını çocuğun ağzına sokup çıkarır; böylelikle çocuğun dilinin çözüleceğine inanılır. ${ }^{64}$

Çocuklarla ilgili diğer inanışlar da şu şekildedir. Kırkı çıkmamış bir bebeğin tırnakları kesilirse o çocuğun hırsız olacağına, küçük çocukların üzerinden atlanıldığında boylarının kısa olacağına; boyu ölçülen çocuğun cüce kalacağına, yürüyemeyen çocukların ayaklarına ip bağlayarak Cuma namazından sonra ilk çıkan kişiye ip kestirilirse çocuğun yürüyeceğine inanılır. ${ }^{65}$

Uluova yöresinde çocukların vücut yapılarına bakılıp kendileriyle ilgili bazı özelliklerin olacağına inanılır. Başı büyük olan çocukların zeki, küçük olanların ise aklının az olduğuna inanılır. Alnı dar olan çocukların sıkıntılı, alnı enli olanların kötü huylu olacağına inanılır. Kulağı büyük olanın tembel olacağına, küçük kulaklı kimselerin yalancı olacağına; kaşlarının ucu ince olanların fitneci, kaşlarının kılları çok olanların üzüntü çekeceğine; kaşlarının arası açık olanların iyi, kaşları çatma olanların, yalancı olacağına inanılır. Kara gözlülerin itaatkâr olacağına, mavi gözlü olanların nazar ettiğine inanılır. Burnu uzun olanların şehvete düşkün, burnu kısa olanların korkak olduğuna inanılır. Büyük ağızlı olan çocukların cesur, küçük ağızlı olanların korkak olacağına inanılır. ${ }^{66}$

\section{ELAZIĞ İLİ ULUOVA YÖRESİ DOĞUMLA İLGILİ HALK İNANIŞLARININ DEĞERLENDİRILMESI}

İnsan hayatının başlangıcı olan doğum, içerisinde barındırdığı olağanüstülükler, zorluklar, korkular, ümitler ve çeşitli inanışlarıyla, geçmişin günümüze aktarılmasında önemli bir geçiş dönemidir. Bugün doğum olayı ile ilgili yaşatılan ve insanların hatıralarında kalan inanışlar, insanların zaman içerisinde karşılaşmış olduğu din, inanç, kültür, akım ve sistemlerden etkilendiğini ve bunlara kendilerinden de bir şeyler katarak geliştirdiklerini görüyoruz.

\footnotetext{
${ }^{63}$ Firdevs Karataş, 1951, Şahsuvar Köyü; Naciye Güneş,1947, Korucu Köyü

${ }^{64}$ Fethiye Çalışkan, 1942, Şahsuvar Köyü; Firdevs Bıyıkl1, 1939, Konakalmaz Köyü

${ }^{65}$ Nesrin Ceyhan, 1971, Kuyulu Köyü; Güllü Tan, 1957, Sarıyakup Köyü; Sülbiye Danış, 1956, Sarıyakub Köyü

66 Firdevs Bıyıklı, 1939, Konakalmaz Köyü; Fethiye Çalışkan, 1942, Şahsuvar Köyü;
} 


\section{Elazığ İli Uluova Yöresindeki Doğumla İlgili Halk İnanışlarının Dinler Tarihi Açısından}

Değerlendirilmesi

Uluova yöresinde ailelerin hayırlı bir çocuk sahibi olabilmek için Allah'a dua etmeleri; insanı yaratanın, doğumuna vesile olanın ve yaşamasına izin verenin yüce Allah olduğu inancı İslami gelenekle alakalıdır. Ayrıca çocuk, bir evin neşesi, anne ve babanın teselli kaynağıdır.

Uluova yöresinde yapmış olduğumuz çalışmalarda doğumla ilgili olarak, ailenin, "ocak, baba ocă̆l" ; çocuğun da "çocuk, ailede ocağl tüttürür" gibi ifadelerle kutsanması, başlangıçtaki Türk inançlarından kaynaklanan ve ailenin sürekliliğini sağlayan çocuğun önemini ortaya koymaktadır. Ayrıca ailenin ocakla bağdaştırılması, eski Türklerdeki demire verilen değerle ilgilidir. Ocağın kutsallaştırılması da ateşten gelmektedir. Dört asli unsurdan biri olan ateş, arıtıcı, 1sıtıcı ve kötülüklerden uzaklaştırandır ${ }^{67}$. Eski Türklerde demir, Tanrı tarafından gökten indirilen, ruhu olduğuna inanılan ve kötü ruhları kovduğuna inanılan kutsal bir madendir. Bundan dolayı Türkler demirin koruyuculuk ve kurtarıcılık unsurunun olduğuna inanmışlardır ${ }^{68}$.

Elazığ ili Uluova yöresinde çocuğu olmayan çiftlerin ulu ve bilge kişilerin türbe ve mezarlarını ziyaret etme geleneği vardır. Bu ziyaretlerde taş yapıştırma, buğday serpme, kutsal kabul edilen ağaçlara renkli iplik ve çaputlar bağlama, ${ }^{69}$ ziyaret edilen delikli taşlara, kutlu pınar başlarına ve tepebaşlarına; "para, şeker, ekmek, meyve ve çamaşır" gibi nesneleri bıraktıkları görülür. Nazardan koruyacağı inancı ile çocukların omuzlarına; "muska, mavi boncuk veya nazarlık" sayılabilecek figürleri asma gibi "saçı" ile ilişkili inanışların, yine başlangıçtaki Türk inançlarının bir bakiyesi olan, saçı saçma pratiklerine rastlanılmıştır. Nitekim gelin, erkek evine getirildiği zaman, gelinin kaynanası tarafından, gelinin ve damadın başına "buğday, para, dar, şeker, leblebi, kuru üzüm, badem, elma" vb. nesnelerden oluşan saçıyı, uğur, bolluk ve bereket getirmesi inancı ile gelinin başına serper. Burada saçı olarak serpilen nesneler, eski Türk inançlarında, "Gök Tanrı"ya, ata ruhlarına ve "yer-su" iyelerine sunulan kansız kurbanların izlerini taşımaktadır. ${ }^{70}$

Uluova Yöresinde çocuğu olmayan kadınların yapmış olduğu uygulamalardan biri de yatır ve türbe ziyaretleridir. Bu yerlere giden kadınlar, dua eder ve kurban keserler. Çocukları olduktan sonra da bu yerlerde kurban keserler ve insanlara ziyafet verirler. Kurban ibadeti birçok inanç sistemlerinde olduğu gibi, Anadolu'nun çoğu yerinde de görülmektedir. Üzerinde durulması gereken bir husus ta çocuğu olmayan, hasta olan, kırklı kadınların ve hasta çocukların hocaya okutulmasıdır. Gerek Uluova ve çevresinde gerekse de Anadolu'nun birçok yerinde Eski Türk Dini'nin kalıcı izlerinden olan, hastalıklar ve başka amaçlarla hocalara başvurma geleneğidir. Bu gelenek içerisinde eski Türk kamlarının dini-sihri birçok uygulamalarını Türklerin İslam'ı kabulü ile birlikte İslami motiflere bezeyerek meşrulaştırmışlardır. Gagauz Türklerinde " $b a-b u$ " (yaşlı kadın)lara okunma âdeti eski Türk kamlarının yukarıda sözü edilen uygulamalarının devamının bir başka örneğini oluşturmaktadır ${ }^{71}$

Çocuğu yaşamayanların çocuğun muhafazası için aldıkları tedbirler gerek İslam öncesi ve sonrası Türklerde aynıdır. Örneğin "Yakutlar, aileye musallat olan ölüm ruhunu aldatmak için

\footnotetext{
${ }^{67}$ Sedat Veyis Örnek, Sivas ve Çevresinde Hayatın Çeşitli Safhalarıyla İlgili Batıl İnançlar ve Büyüsel İşlemlerin Etnolojik Tetkiki, Ankara 1966, s. 115.

${ }^{68}$ Sami Kılıç, "Çocuk Sahibi Olmak İçin Dinsel-Sihirsel Bir Uygulama: Irkatma Ocağı (Takmak Köyü- Elif İskeçe Örneği)", s. 305

${ }^{69}$ Harun Güngör, “Eski Türk Dini”, Yaşayan Dünya Dinleri, I. Bask1, Ankara 2007, s. 535.

70 Günay Tümer-Abdurrahman Küçük, Dinler Tarihi, Ocak Yay. Ankara 2002, s. 79-82; Ünver Günay-Harun Güngör, Başlangıçlarından Günümüze Türklerin Dini Tarihi, s. 80.

${ }^{71}$ Harun Güngör, Türk Bodun Bilimi Araştırmaları., s. 107.
} 


\section{Elazığ İli Uluova Yöresindeki Doğumla İlgili Halk İnanışlarının Dinler Tarihi Açısından} Değerlendirilmesi

çocuğu komşulardan birine satarlar." "Çocuğu yaşamayan Başkurtlar da, Müslüman oldukları halde, ölüm meleğini şaşırtmaya çalışırlar". Çocuk doğduğu gibi, ebe çocuğu eline alıp dışarı çıkar. Birkaç ev dolaştıktan sonra ebe babasının evinden seslenir: "Yabancı ülkeden bir çocuk getirdim, satın alan var mı?” der. Pazarlık başlar. Çocuk ağırlı̆̆ında demir verilip satın alınır. Çocuğa: "Demir" ya da "satılmış" gibi isimler verirler". Çocuğun yaşamasını sağlamak için "Yaşar, Ölmez, Dursun, Durmuş, Durali, Durdu" gibi adlar verilir. ${ }^{72}$ Eski Türk inançlarının kalıntıları olan bu ve benzeri uygulamalara Uluova ve çevresinde de rastlamaktayı. Nitekim insanlar tarihin her devrinde çocuklarını korumak için bazı ritüeller geliştirmiş ve inanış haline getirmişlerdir.

Yörede sarılık tedavisinde, çocuğa sarı tülbent örtülmesi, altın madeninden yapılmış bir takının suya atılıp bu su ile çocuğa banyo yaptırılması, çocuğun alnına, kulağının arkasına ve topuğuna sarılık ocağındaki kişi tarafından kesici bir aletle, kan akıttırılması ve çocuğun alnına sürülmesi gibi hususlar ön plana çıkmaktadır. Uluova yöresinde nazar tedavisinde kullanılan " $t u z$, $s u$, kurşun, demir ve ateş" gibi unsurlar bazı din ve inanç sistemlerinde ön plana çıkmaktadır. Eski Türklerde demir ateş ve su önemli bir yer tutar. Yörede uygulanan kurşun dökme ve tuz çevirme gibi ritüellerde kullanılan kurşunun ateşte eritilip suya bırakılması neticesinde hastalıkların tedavi edilmesi inancı; demir, ateş ve suyun kutsallığına ait başlangıçtaki inançlarla, dolayısıyla "koruyucu ruh" inancıyla bütünleşmektedir ${ }^{73}$

Uluova yöresinde tespit ettiğimiz ve loğusa kadınlara zarar verdiğine inanılan "Albastı ve Karabasan"1n Anadolu'nun birçok yerinde benzer şekillerde görülmesiyle birlikte; hemen hemen bütün Türk topluluklarında da görülmektedir. Albastı'dan korunmak için yapılan uygulamalarda biraz farklılık gözükse de öz itibariyle benzerliklere rastlanmaktadır. Türk dünyasında albastı kötü ruhlu bir dev olarak tasavvur edilir, loğusalara zarar verir ve hatta onları öldürebilir. Bunun için loğusaları albastının kötülüklerinden korumak gerekir. Kadın doğum yaptığında onu kötü ruhların etkisinden korumak amacıyla loğusanın yastığının altına makas koymakta, odada süpürge bulundurmakta ve kırk gün mum yakmak adet olmuştur. Buradaki makas figürüyle yöredeki iğne ve çuvaldız figürünün demirden yapılmış olması ve delici olması benzerlik göstermektedir. Ayrıca Albastı'nın kötü bir ruh olduğu, loğusa kadına zarar verdiği ve hatta loğusa kadını öldürdüğü inanışı Eski Türk inançları ile benzerlikler göstermektedir.

\section{SONUÇ}

Elazı̆̆ ili Uluova yöresindeki doğumla ilgili halk inanışlarının Dinler Tarihi açısından değerlendirilmesi başlıklı bu araştırmada halk inanışlarının ve uygulamalarının toplum nezdindeki yerine dikkat çekilmiştir. Nitekim halk inanışları toplumlara hem maddi hem de manevi anlamda zenginlik kazandıran, toplumların kendi ayakları üzerinde durabilmelerine yardımcı olan, kendi geçmişleri ile gelecekleri arasında köprü kuran, çağdaş dünyanın altından kalkamadığı sorunlara çözüm arayan ve yerini hiçbir şeyle dolduramadığı sözlü, yazılı ve uygulamalı ritüellerdir. Halk inanışları kendi bünyelerinde büyüsel ve dinsel motifleri barındırmaktadır. Bu uygulamalar bazen örf, âdet, gelenek ve görenek; bazen de halk hekimliği, alternatif tıp, sağaltma, ocak kültü ve psikolojik tedavi yöntemi olarak karşımıza çıkmaktadır.

\footnotetext{
72 Abdulkadir İnan, Tarihte ve Bugün Şamanizm, Ankara 1972, s. 174.

${ }^{73}$ Ünver Günay-Harun Güngör, Başlangıçlarından Günümüze Türklerin Dini Tarihi, s. 77.
} 


\section{Elazığ İli Uluova Yöresindeki Doğumla İlgili Halk İnanışlarının Dinler Tarihi Açısından}

Değerlendirilmesi

Elazığ ili Uluova yöresindeki doğumla ilgili halk inanışları Dinler Tarihi açısından değerlendirilirken, doğum olayının ne ifade ettiği, doğum yapacak kadının ve doğacak çocuğun nelere sahip olması gerektiği, doğumdan sonra çocuğu ve annenin nasıl korunacağı ile ilgili çarpıcı sonuçlara ulaşılmıştır.

Uluova yöresinde doğum öncesi halk inanışları, kadının hamile kalabilmesi için yapılan uygulamalar, hamile kaldıktan sonra çocuğun cinsiyeti ve sağ olarak doğabilmesi için geçecek zaman içerisindeki uygulamalar ve kadının sağlı̆̆ının korunmasıyla ilgili uygulamalar mevcuttur. Doğumdan sonra erkek çocukların sünnet ettirilmeleri, kirvelik ve sünnet anında yapılan uygulamalar dikkat çekicidir. Doğum ile ilgili inanış ve uygulamaların genellikle Anadolu'daki inanışlarla benzerlik gösterdiği, daha çok Orta Asya Türk kültürüne kaynaklık eden, Geleneksel Türk Dini ile yakından alakalı olduğu ifade etmek mümkündür.

Geleneksel Türk kültürünün yaşatılmaya çalışıldığı Uluova Yöresinde halk İnanışları, burada yaşayan insanların atalarının tarihi süreçte karşılaştıkları bütün din, inanç, kültür ve sistemlerde kendilerine ve karakterlerine uygun olan, öz itibariyle de değişime yol açmayan bazı uygulamaları, kendi inanışlarıyla yoğurmaları sonucunda bugüne kadar taşımaya çalıştıklarını ifade etmek mümkündür. Bu inanışlar Eski Türklerin ve beraberinde yaşadıkları toplumların hayatlarında yaşattıkları pratikleri, İslam Dinini kabul ettikten sonra da bazı İslami figürlerle kaynaştırmaları sonucu, yeni bir hale dönüştürmeleriyle meydana gelmiştir.

Elazığ ili Uluova yöresindeki doğumla ilgili halk inanışlarının Dinler Tarihi açısından değerlendirilmesini konu edinen bu çalışmada ifade etmemiz gereken en önemli hususlardan biri; çoğunlukla yeteri kadar önemsemeyen ya da önemsizmiş gibi zikredilen birçok inanışın ve uygulamanın aslında sahip olduğumuz değerleri ifade ettiği görülmektedir. Nitekim bazı örf, âdet, gelenek ve göreneklerin aslında halk inanışları yoluyla yaşatıldığı aşikârdır.

Halk inanışlarının esas itibariyle toplumları ayakta tutması ve kuşaklar arası bağları güçlendirmesi ise bir diğer önemli husustur. Ayrıca halk inanışları sadece toplumları ayakta tutmak ve köprü olmakla kalmamakta aynı zamanda kardeşlik, barış, birlik ve beraberliği sağlamak suretiyle binlerce yıldır yaşadığımız bu toprakların her zerresine işlemiş olan Türk Kültürü ve Türk Medeniyetinin yozlaşmasını önleyen başlıca değerleri de bünyesinde barındırmaktadır.

Söz konusu bünyenin bozulmasına izin vermemek için yaşayan bir kültür hazinesi olan halk inanışlarını, halkımızın dini ve milli değerlerine zarar vermeyecek şekilde varlığını devam ettirmesini sağlamak gerekir. Zira atalarımızın binlerce yıllık tecrübeleriyle yoğurduğu, milli benliğimizin harcı olan halk inanışlarını yeni nesillere ilim ve kültür yoluyla aktarmak, ilmi ve vicdani görevler arasında yer almaktadır.

\section{KAYNAKÇA}

Abdulkadir İnan, Tarihte ve Bugün Şamanizm, Ankara 1972.

Abdulkadir Kıyak, Elazığ ve Yöresinde Ziyaret Yerleri, Ankara 2012.

Abdulkadir Kıyak, Sinemilli Aleviliği (İnanç ve İbadet Anlayışlarının Dinler Tarihi Açısından Değerlendirilmesi), Ankara 2018.

Bahaeddin Ögel, Türk Kültür Tarihine Giriş, C.IV., Ankara 1978. 
Günay Tümer-Abdurrahman Küçük, Dinler Tarihi, Ocak Yay. Ankara 2002.

Harun Güngör, "Eski Türk Dini”, Yaşayan Dünya Dinleri, I. Baskı, Ankara 2007.

Harun Güngör, Türk Bodun Bilimi Araştırmaları, II. Baskı, İstanbul 2008.

Hikmet Tanyu, Türklerin Dini Tarihçesi, İstanbul 1978.

İbrahim Kafesoğlu, Türk Milli Kültürü, İstanbul 1993.

Mircea Eliade, Dinler Tarihi, İnançlar ve İbadetlerin Morfolojisi, Çev. Mustafa Ünal, Konya 2005.

Rıfat Araz, Harput'ta Eski Türk İnançları ve Halk Hekimliği, Atatürk Kültür Dil ve Tarih Yüksek Kurumu Atatürk Kültür Merkezi Yayını No: 108, Ankara 1995.

Sami Kılıç, "Çocuk Sahibi Olmak İçin Dinsel-Sihirsel Bir Uygulama: Irkatma Ocağı (Takmak Köyü- Elif İskeçe Örneği)",

Sami Kılıç, "Uşak ve Çevresinde Yağmur Yağdırma Uygulamaları, Takmak Köyü Örneğı̀” , Turkish Studies- İnternational Periodical For The Languages, Litarature, and History of Turkish or Turkic- Volume 6/1 Kış, 2011.

Sami K1lıç, Türk Halk İnanışlarında Yiyecek ve İçecekler, Elazığ 2012.

Sedat Veyis Örnek, 100 Soruda İlkellerde Din, Büyü, Sanat, Efsane, İstanbul 1971.

Sedat Veyis Örnek, Sivas ve Çevresinde Hayatın Çeşitli Safhalarıyla İlgili Batıl İnançlar ve Büyüsel İşlemlerin Etnolojik Tetkiki, Ankara 1966.

Sedat Veyis Örnek, Türk Halk Bilimi, Ankara 2000.

Ugo Bianchi, Dinler Tarihi Araştırma Yöntemleri, Çev. Mustafa Ünal, Kayseri 1999.

Ünver Günay- Harun Güngör, Başlangıçlarından Günümüze Türklerin Dini Tarihi,

Ünver Günay, Âşık Tarzı Şiir Geleneği ve Rüya Motifi, Ankara 1986.

Ünver Günay-Harun Güngör, Başlangıçlarından Günümüze Türklerin Dini Tarihi,

Yaşar Kalafat, Doğu Anadolu'da Eski Türk İnancının İzleri, Berikan Yayınevi, Ankara 2010.

\section{KAYNAK KISŞiLER}

Abdullah Tokgöz, 1950, Gedikyolu Köyü

Adnan Buytoz, 1961, Ballıca Köyü

Ahmet Çelik, 1955, Ballıca Köyü

Alaattin Bayrak, 1925, İçme

Aladin Aksar, 1954, Yenikapı Köyü

Ali Ayaz, 1960, Yalnız Köyü

Ali Orhan, 1952, Konakalmaz Köyü

Ali Özcan, 1951, Mollaköy Köyü 
Asiye Özcan 1945, Mollaköy Köyü

Aslan Ural, 1972, Konakalmaz Köyü

Atike Ayaz, 1956, Yalnız Köyü

Aydın Akbaş, 1947, Ürünveren Köyü

Aydın Pala, 1945, Şahsuvar Köyü

Aydın Toraman, 1939, Akçakiraz Köyü

Aygün Karakaya, 1967, Aşağ İçme

Ayhan Süme, 1973, Akçakiraz

Ayişe Aygün, 1939, Konakalmaz Köyü

Aysel Şanlı, 1948, Elmapınar Köyü

Baki Özçelik, 1932, Gözebaşı Köyü

Bedrettin Karakaya, 1954, Aşağı İçme Köyü

Behçet Yavuz, 1950, İçme Köyü

Cahide Coşkuner, 1961, Ürünveren Köyü

Celal Sertkaya, 1966, Yünlüce Köyü

Cemal Aksu, 1946, Gedikyolu Köyü

Cemal Güllecemal, 1977, Yolüstü Köyü

Cengiz Y1lmaz, 1965, Yukarı İçme Köyü

Cihan Çınar, 1964, Yolüstü Köyü

Dinçer Karataş, 1963, Sarıkamış Köyü

Dursun Çetinkaya, 1953, Şahsuvar Köyü

Eco Şahin, 1941, Gedikyolu Köyü

Emine Alkan, 1939, Şahsuvar Köyü

Emine Ökmen, 1972, Yedigöze Köyü

Erdem Akman, 1961, Yurtbaşı Köyü

Ersin Soğuktaş, 1971, Kuyulu Köyü

Fahriye Kavuran, 1960, Kuyulu Köyü

Faik Üstündağ, 1937, Yukarı İçme Köyü

Farız Beyhan, 1940, Yukarı İçme Köyü

Fatma Çakabay, 1947, Korucu Köyü

Fatma Çakmak, 1964, Dereboğazı Köyü 
Fatma Iş1k, 1965, Koçkale Köyü

Fatma Yalçın 1956, Gedikyolu Köyü

Fatma Y1lmaz, 1966, Elmapınarı Köyü

Fethi Bağkesen, 1957, Şahsuvar Köyü

Fethiye Çalışkan, 1942, Şahsuvar Köyü

Fethiye Taş, 1938, Yurtbaşı Köyü

Feti Bağkesen, 1957, Şahsuvar Köyü

Fikrinaz Aksu, 1950, Şahsuvar Köyü

Fikriye Efe, 1966, Koçkale Köyü

Firdevs Bıyıkl1, 1939, Konakalmaz Köyü

Firdevs Karataş, 1951, Şahsuvar Köyü

Firdevs Yüceer, 1950, Şahsuvar Köyü

Gülay Polat, 1953, Akçakiraz

Güler Polat, 1953, Akçakiraz

Güler Şirin, 1956, Şahsuvar Köyü

Güllü Kama, 1940, Elmapınarı Köyü

Güllü Tan, 1957, Sarıyakup Köyü

Güney Erol, 1948, Sarıyakup Köyü

Habib Bıyıklı, 1960, Konakalmaz Köyü

Hadice Akbaş, 1954, Ürünveren Köyü

Hakan Kaynak, 1957, Şahsuvar Köyü

Hamide Güler, 1969, Ürünveren Köyü

Hanım Çimen, 1960, Tadım Köyü

Hasan Ayaz, 1957, Yalnız Köyü

Hasan Bulut, 1970, Yolüstü Köyü

Hasan Egün, 1940, Aşağı İçme Köyü

Hasan Kaya, 1963, Koçkale Köyü

Hatice Koç, 1969, Tadım Köyü

Hayri Bayram, 1940, Şahsuvar Köyü

Hıdır Arslan, 1958, Tadım Köyü

Hilmi Köse, 1961, Yurtbaş1 Köyü 
Huriye Aydın, 1938, Şahsuvar Köyü

Hülya Tunç, 1965, Yukarı İçme Köyü

Hüseyin Baykal, 1952, Yünlüce Köyü

Hüseyin Karakaya, 1954, Aşağ1 İçme Köyü

Hüseyin Öztürk, 1937, Şahsuvar Köyü

Hüseyin Turhan, 1956, Kuyulu Köyü

Hüsna Ayaz, 1962, Yalnız Köyü

İbrahim Tan, 1956, Sarıyakub Köyü

İnci Dündar, 1961, Korucu Köyü

İsabet Yavuz, 1932, Mollaköy Köyü

Kemal Çelik, 1931, Akçakiraz Köyü

Kıymet Erol, 1955, Sarıyakup Köyü

Kıymet Karakoç, 1955, Elmapınarı Köyü

Mahmut Öztekin, 1936, Gözebaş1 Köyü

Maviye Ateşoğlu, 1960, Elmapınarı Köyü

Mehmet Bayram, 1950, Gedikyolu Köyü

Mehmet Coşkuner, 1956, Ürünveren Köyü

Mehmet Emin Açıkgöz, 1948, Yolüstü Köyü

Mehmet Genç, 1964, Tadım Köyü

Mehmet Gülcemal, Yolüstü Köyü

Mehmet Türkoğlu, 1945, Koçkale Köyü

Metin Gönayl1, 1969, Yedigöze Köyü

Miyase Gülcemal, 1950, Yolüstü Köyü

Miyase Gülcemal, 1977, Yolüstü Köyü

Muhammed Çak, 1963, Ballıca

Muhammed Çak, 1963, Ballıca Köyü

Muhlise Parlakdemir, 1940, Şahsuvar Köyü

Murat Yılmaz, 1961, Elmapınarı Köyü

Murat Yurdakul, 1981, Sarıkamış Köyü

Musa Tokmak, 1957, Gedikyolu Köyü

Mustafa Başpınar, 1938, Yukarı İçme Köyü 
Mustafa Ergün, 1968, Aşağı İçme Köyü

Mustafa Kaya, 1954, Koçkale Köyü

Mustafa Ökmen, 1972, Yedigöze Köye

Mustafa Sönmez, 1930, Gözebaşı Köyü

Mustafa Tan, 1944, Akçakiraz Köyü

Mustafa Yalçın, 1950, Gedikyolu Köyü

Mustafa Yıldırım, 1956, Tadım Köyü

Müfide Karataş, 1959, Şahsuvar Köyü

Mümtaz Açıkgöz, 1968, Yolüstü Köyü

Münür Sarptaş, 1949, İçme Köyü

Mürüvet Özcan, 1925, Mollaköy Köyü

Mürüvet Ural, 1951, Yedigöze Köyü

Müzeyyen Çak, 1960, Ballıca Köyü

Naci Meşe, 1953, Tadım Köyü

Naciye Güneş, 1947, Korucu Köyü

Nadir Kara, 1935, Yurtbaşı Köyü

Nahide Deringöl, 1964, Şahsuvar Köyü

Naile Aygün, 1956, Konakalmaz Köyü

Naim Koç, 1959, Korucu Köyü

Nazife Yıldırım, 1965, Tadım

Nazmiye Gül, 1958, Şahsuvar Köyü

Nazmiye Gür, 1958, Şahsuvar Köyü

Nazmiye Sarptaş, 1958, İçme

Nebahat Yavuz, 1967, MollaKöy Köyü

Necip Taş, 1961, Yünlüce Köyü

Nesrin Ceyhan 1971, Kuyulu Köyü

Nuray Gönayl1, 1968, Yedigöze Köyü

Nurettin Sever, 1941, Gedikyolu Köyü

Ömer Karakoç, 1951, Elmapınar Köyü

Önder Çevik, 1970, Sarıkamış Köyü

Özgül Arslan 1968, Tadım Köyü 
Özgür Güler, 1970, Ürünveren Köyü

Pakize Aydın, 1939, Gedikyolu Köyü

Rahmi Demir, 1977, Sarıkamış Köyü

Ramazan Işık, 1957, Koçkale Köyü

Ramazan Karakaya, 1960, Aşağı İçme Köyü

Reşat Ateşoğlu, 1965, Elmapınarı Köyü

Rıfat Şanl1, 1945, Elmapınarı Köyü

Sabahattin Aksar, 1957, Yenikapı Köyü

Safiye Ergün 1966, Aşağı İçme Köyü

Safiye Ergün, 1966, Aşağı İçme Köyü

Seçkin Vural, 1967, Yedigöze Köyü

Selami K1lınç,1964, Şahsuvar Köyü

Sema Kaya, 1970, Koçkale Köyü

Semahat Mutlu, 1963, Aşağı İçme Köyü

Sevim Gökdere, 1955, Mollaköy Köyü

S1tk1 Bulut, 1940, Yurtbaş1 Köyü

Songül Turhan, 1968, Kuyulu Köyü

Suat Koç, 1956, Tadım Köyü

Sülbiye Danış, 1956, Sarıyakub Köyü

Şahabettin Bayram, 1946, Korucu Köyü

Şahver Danış, 1954, Sarıyakup Köyü

Şahver Yavuz, 1957, İçme Köyü

Şükran Şanlı,1953, Elmapınarı Köyü

Tacettin Çakmak, 1965, Dereboğazı Köyü

Tahir Tuncel, 1948, Korucu Köyü

Tayyibe Karakaş, 1944, Sarıkamış Köyü

Tekçe Çetindağ, 1938, Akçakiraz

Türkan Rençber, 1934, Gözebaş1 Köyü

Veli Başbaydar, 1968, Yünlüce Köyü

Yaşar Çetinkaya, 1973, Ürünveren Köyü

Zabite Ural, 1950, Konakalmaz Köyü 
Elazığ İli Uluova Yöresindeki Doğumla İlgili Halk İnanışlarının Dinler Tarihi Açısından Değerlendirilmesi

Zübeyde Buytoz 1973, Ballıca

Zübeyde Aktaş, 1970, Yalnız Köyü

Zübeyde Buytoz, 1973, Ballıca Köyü

Zülfikar Timarc1, 1950, Yedigöze Köyü

Zülfü Aktaş, 1953, Yalnız Köyü 